\title{
Scaffolds Based Bone Tissue Engineering: The Role of Chitosan
}

\author{
Ana Rita Costa-Pinto, Ph.D.,, ${ }^{1,2}$ Rui L. Reis, Ph.D.,, ${ }^{1,2}$ and Nuno M. Neves, Ph.D. ${ }^{1,2}$
}

As life expectancy increases, malfunction or loss of tissue caused by injury or disease leads to reduced quality of life in many patients at significant socioeconomic cost. Even though major progress has been made in the field of bone tissue engineering, present therapies, such as bone grafts, still have limitations. Current research on biodegradable polymers is emerging, combining these structures with osteogenic cells, as an alternative to autologous bone grafts. Different types of biodegradable materials have been proposed for the preparation of three-dimensional porous scaffolds for bone tissue engineering. Among them, natural polymers are one of the most attractive options, mainly due to their similarities with extracellular matrix, chemical versatility, good biological performance, and inherent cellular interactions. In this review, special attention is given to chitosan as a biomaterial for bone tissue engineering applications. An extensive literature survey was performed on the preparation of chitosan scaffolds and their in vitro biological performance as well as their potential to facilitate in vivo bone regeneration. The present review also aims to offer the reader a general overview of all components needed to engineer new bone tissue. It gives a brief background on bone biology, followed by an explanation of all components in bone tissue engineering, as well as describing different tissue engineering strategies. Moreover, also discussed are the typical models used to evaluate in vitro functionality of a tissue-engineered construct and in vivo models to assess the potential to regenerate bone tissue are discussed.

\section{Introduction}

B ONE TISSUE, WHEN INJURED, leads to dramatic changes in the quality of life of patients. It can limit the ability to perform basic tasks, such as walking and frequently causes social and psychological problems. The current clinically available solutions for these problems rely on bone graft transplants (autologous, allogeneic, and xenogenic), bone transport methods (Ilizarov technique), and implants based on different types of materials. More than 2.2 million bone graft procedures (autologous bone graft and banked bone) take place annually worldwide. ${ }^{1,2}$ Those procedures ensure adequate bone healing of many skeletal problems, such as nonunion fractures, cervical and lumbar spine fusion, joint arthrodesis, or revision arthroplasty. Bone grafting is a strong and mature business generating sales of more than $\$ 2.5$ billion a year. $^{3}$ Autografts are considered the gold standard for bone repair. However, some complications may occur, such as bone nonunions and blood loss, which increases the need for blood transfusions. ${ }^{4-6}$ Moreover, besides being an expensive procedure, there is a limited supply of tissue and it causes significant donor-site morbidity. 7,8 Allografts are typically nonvital (dead) bone harvested from a cadaver and then processed using a freeze-drying method that extracts all the water via a vacuum drying. These types of grafts avoid donor-site morbidity but present a potential risk for disease transmission and severe immune response by the patient. ${ }^{9}$ Similar to allogeneic bone, xenogenic bone is nonvital bone derived from other species, mainly from bovine origin. Because the potential for immune rejection and contamination by viral proteins is higher in bovine bone than in human cadaver bone, xenograft material is processed at very high temperatures. The Ilizarov methodology consists of an osteotomy followed by bone distraction by extendable fixation devices. This technique avoids problems related with the osseointegration of bone grafts, but requires longer periods of treatment (12-18 months) and can be quite painful for the patient. ${ }^{10}$ The aforementioned limitations justify the development of new therapies using alternative concepts that are currently the focus of intense research efforts.

Bone has a notable regenerative ability but a considerable amount of bone loss or the development of an adverse microenvironment can hinder this capacity, such as in cases of severe trauma, developmental deformities, revision surgeries, and tumor resection. ${ }^{11,12}$ In these cases, bone tissue engineering holds the promise of great therapeutic potential. ${ }^{13}$

\footnotetext{
${ }^{1} 3 \mathrm{~B}$ 's Research Group-Biomaterials, Biodegradables and Biomimetics, Department of Polymer Engineering, Headquarters of the European Institute of Excellence on Tissue Engineering and Regenerative Medicine University of Minho, Guimarães, Portugal.

${ }^{2}$ ICVS/3B's-PT Government Associate Laboratory, Braga/Guimarães, Portugal.
} 
Bone tissue engineering may constitute the needed breakthrough technology to solve the problem of bone shortage in various destructive clinical conditions and deformities by providing functional tissue-engineered biological substitutes. ${ }^{14}$ The most promising strategy used in this field is based on the seeding and in vitro culture of primary osteoblasts or adult stem cells (ASCs) differentiated into the osteogenic phenotype on three-dimensional (3D) scaffolds (synthetic, natural, or ceramic). These constructs would be subsequently implanted into a bone defect. The cells would synthesize the extracellular matrix (ECM) of new bone tissue, whereas the scaffold would provide an adequate $3 \mathrm{D}$ environment for the cells to adhere, proliferate, and differentiate. The scaffolds will not only be temporary 3D support for cells to create new bone, but also space filling and controlled local release device of signaling molecules. To accomplish all of these goals, scaffolds should meet stringent requirements, such as biodegradability at a rate that is compatible with the rate of new tissue formation. Other important properties include biocompatibility with host tissues, nontoxicity and nonimmunogenicity, appropriate mechanical properties, adequate porosity, and morphology. ${ }^{15-17}$ All of these properties are essential to facilitate and guide cell ingrowth and transport of gases, metabolites, nutrients, and signaling molecules, both within the scaffold and between the scaffold and the native local environment.

The selection of the most suitable material to produce a scaffold to be used in bone tissue engineering applications is a determinant step, since its properties will determine its final characteristics. Biodegradable polymers, either synthetic or natural, are the most appropriate substrates for cells to attach, grow on, and maintain a differentiated phenotype. In recent years, naturally derived polymers have been increasingly proposed for the referred application. In our group, we have been working with natural polymers, such as in starch, ${ }^{18-22}$ chitosan, $^{23-27}$ gellan gum, ${ }^{28-31}$ soy, and silk. ${ }^{33,34}$ Our strategy is to mimic nature and for that we have been using these polymers to design functional microenvironments stimulating tissue morphogenesis. In particular, chitosan has shown an excellent combination of properties and it has been demonstrated that it is a suitable biomaterial for the development of scaffolds for bone tissue engineering. Chitosan can be used either alone $e^{23,35-41}$ or in combination with other biodegradable polymers, such as aliphatic polyesters, ${ }^{25,27,42-45}$ other natural polymers such as starch $^{26,46,47}$ or silk, ${ }^{48,49}$ or with ceramics such as hydroxyapatite (HA). ${ }^{24,50-58}$

This article aims to provide an overview of the most important concepts in bone tissue engineering and a review of chitosan-based scaffolds proposed to use in bone regeneration. The potential of this biomaterial as a suitable substrate to support osteogenic differentiation of mesenchymal stem cells (MSCs) will also be explored.

\section{Brief Overview of Bone Biology}

Bone is a dynamic and complex tissue evolving and adapting to various stimuli throughout one's lifetime. ${ }^{59}$ It plays crucial roles in both mechanical support and mineral homeostasis. ${ }^{60}$ Within a skeletal element, there are different morphologies of bone, such as cortical and trabecular bone. Cortical bone is a compact structural tissue, with only $10 \%$ porosity, being $80 \%$ of the mass of an adult human skeleton. Trabecular bone is a spongy structure with $50 \%-90 \%$ porosity, filled with bone marrow. The majority of bones are covered by a highly vascularized fibrous connective tissue, the periosteum. ${ }^{61}$ Five different cell types are involved in bone maintenance and remodeling: MSCs, bone-lining cells, osteoblasts, osteocytes, and osteoclasts. Within the bone structure, MSCs are found in the bone marrow ${ }^{62-65}$ and also in the periosteum. ${ }^{66}$ Bone marrow is composed of hematopoietic tissue and the supporting stroma. ${ }^{67}$ Marrow stromal cells, originally thought to only contribute to the hematopoietic microenvironment, later came to the center stage with the recognition of being the stem/progenitor cells of skeletal tissues. ${ }^{63}$ Human autologous bone marrow associated with macroporous HA scaffolds was implanted in large bone segmental defects and shown to promote bone regeneration. ${ }^{68}$ After a 7-year follow-up, ${ }^{69}$ patients presented a complete healing of their defects. Bone-lining cells are flat cells that cover all bone surfaces and are believed to arise from osteoblasts that become inactive. ${ }^{70,71}$ These cells form an important cellular barrier that divides the canalicular network (where osteocytes are present) from other fluids. ${ }^{61}$ Osteoblasts can be derived from MSCs that synthesize the osteoid (nonmineralized organic matrix of the bone, that is, type I collagen, osteocalcin, osteopontin, bone sialoproteins, and bone morphogenetic proteins). ${ }^{72}$ Osteoblasts also have an active role in the vascularization process by secreting morphogens that activate angiogenesis by signaling endothelial cells. ${ }^{73-75}$ Osteocytes are terminally differentiated osteoblasts entrapped within the bone ECM that are involved in the maintenance of ECM and calcium homeostasis. ${ }^{61}$ Osteocytes also sense mechanical stress and communicate signals for bone remodeling and tissue maintenance. ${ }^{76}$ The fifth cell type is the osteoclast, responsible for bone resorption, which is the first stage of the bone remodeling process, followed by bone homeostasis. These cells are large multinucleated cells differentiated from a fraction of monocytes found in peripheral blood. ${ }^{61}$

As with many other connective tissues, one of the main components of bone is its ECM, which in this case is mineralized. Bone ECM is composed of $35 \%$ organic matrix and $65 \%$ mineral matrix. The most abundant mineral in bone ECM is HA, a calcium phosphate crystallized at the surface of collagen fibrils, required to resist bending and compression stresses. ${ }^{59}$ The organic matrix is mainly protein composed of type I collagen (90\%) and the remaining fraction includes up to 200 other noncollagenous proteins, such as glycoproteins, proteoglycans, integrin-binding proteins, and growth factors. $^{59}$

Bones are developed by two main processes: intramembranous and endochondral ossification. ${ }^{77,78}$ Intramembranous ossification is a process that generates flat bones and the skull structure. In this pathway, the embryonic mesenchyme condenses and develops in primary ossification centers, which will eventually fuse to form a network of anastomosing interconnected trabeculae made of woven bone. ${ }^{77}$ After that, periosteum is formed at the surface of trabeculae, further mineralized and part of the intertrabecular connective tissue is transformed in hematopoietic tissue. ${ }^{78}$ Finally, the woven bone is remodeled into a lamellar type of bone. ${ }^{79}$ Endochondral ossification is an osteogenic process through which long bones, vertebrae and the pelvis are 
generated from precursor cartilaginous tissue..$^{80}$ This process starts in the fetus where MSCs differentiate into chondrocytes, converting the condensed mesenchyme into a cartilaginous model of bone that will expand in its extremities, while becoming hypertrophic in the center. These hypertrophic chondrocytes will promote primary ossification by secreting molecules (such as alkaline phosphatase [ALP], type $\mathrm{X}$ collagen, or vascular endothelial growth factor) that will induce calcification of cartilage. This tissue will be resorbed, becoming a structure onto which progenitor cells differentiate into osteoblasts that start to deposit osteoid. After birth, secondary ossification centers develop at the extremity of long bones, allowing the development and growth of bone structure. ${ }^{79}$

\section{Bone Tissue Engineering Strategies}

Bone has an intrinsic self-ability to regenerate, but over a large defect, inherent osseous processes are not able to repair the defect during the patient's lifetime. ${ }^{81}$ Further, diseased bones do not heal properly and, under certain pathological conditions, start damaging themselves. ${ }^{81-83}$ Tissue engineering has emerged as a possible solution for these clinical conditions. Several strategies can be employed to develop new bone tissue. Those strategies may involve the use of an ECM-like structure (scaffold), cells, and/or growth factors. These three basic components need to be well synchronized to achieve a successful tissue engineering therapy. The strategy used for a specific bone defect must be adapted to the clinical state of the patient. Overall, there are primarily three approaches that have been described for tissue engineering strategies: (1) to use engineered on matrices alone, to guide tissue regeneration; (2) to inject autologous, allogeneic, or xenogeneic cells alone; (3) to develop constructs of cells seeded on these matrices. ${ }^{14}$ The first method involves implanting the scaffold at the site of interest, allowing host cells to migrate from the surrounding tissues to colonize the scaffold. The second strategy has the advantage of involving minimal surgical invasion and cells can be manipulated by recombinant gene technology or clonal expansion before injection or infusion. However, this methodology has limitations for bone critical-sized defects, due to the absence of the supporting matrix to keep cells at the defect site. In the last approach, cells are seeded onto the scaffold (construct) and later implanted into the bone defect. Usually, constructs are produced ex vivo before transplantation to a bone defect and over time seeded and/or host cells will synthesize a new ECM, as the scaffold degrades, creating a new functional tissue. This review will focus on the third tissue engineering strategy, exploring the potential use of autologous stem cells cultured in biodegradable scaffolds that will act as ECMs, supporting cell growth and tissue development.

\section{Use of Naturally Occurring Polymers in Scaffolds}

Nature offers a remarkable set of materials with great potential to be used in different fields. The study and use of natural materials comes from ancient times, such as cellulose, which is used to produce paper or silk to produce clothes. In medicine, for example, chitosan is used as a wound-dressing material and collagen as a substitute in reconstructive surgery. Today, powerful tools are available and the micro- and nanostructures of these materials have been described. This new level of knowledge has opened new opportunities to develop materials for other applications, such as scaffolds for tissue engineering. Great efforts have been made to recapitulate the key features of bone ECM by developing structures that mimic this naturally occurring matrix. ECM plays an important role in cell activities, modulating their behavior. ${ }^{84}$ One difficulty in developing such scaffolds is the complexity of recreating microenvironments similar to that found in the tissue of interest. A simple approach to mimic nature is to use naturally occurring materials. Moreover, natural polymers have different functions, such as the role of polysaccharides in cell membranes, intracellular communication and storage, or proteins that are structural materials and catalysts (enzymes) ${ }^{85}$ Natural polymers such as starch ${ }^{18-20,22,86-88}$ or chitosan $^{89-92}$ have been described as biocompatible, biodegradable, and having tailorable degradation rates. ${ }^{86,90}$ Some drawbacks of these biomaterials are the limited mechanical properties and processability or variability between different batches. ${ }^{15}$ Examples of natural polymers commonly used to produce scaffolds are collagen, ${ }^{93-97}$ hyaluronan, ${ }^{98,99}$ alginate, ${ }^{100}$ silk, ${ }^{48,101,102}$ and chitosan. ${ }^{23,37,41}$ These polymers can be combined with other synthetic materials, to improve their processability and mechanical properties. Combinations with $\mathrm{HA}^{103}$ aliphatic polyesters, ${ }^{25,27,104,105}$ or composites of different natural polymers ${ }^{26,46}$ have also been described. Herein a special focus will be given to the natural polysaccharide chitosan, the deacetylated product of chitin obtained from the exoskeleton of crustaceans.

\section{Chitosan as a Natural Origin Biopolymer}

The history of chitosan dates back from the 19th century when Rouget discussed its deacetylated form. ${ }^{106}$ Chitosan is a linear polysaccharide, obtained from the deacetylation of chitin, the primary structural polymer of the exoskeleton of crustaceans, cuticles of insects, and cell wall of fungi. ${ }^{107,108}$ Chitosan is composed of glucosamine and $\mathrm{N}$-acetyl glucosamine with $\beta(1-4)$ link. ${ }^{109}$ Chitosan is the common name for the family of deacetylated chitins, with different degrees of deacetylation. By definition, when the number of $N$-acetyl glucosamine units is higher than $50 \%$, the polymer is considered chitin. On the other hand, when the number of $\mathrm{N}$-glucosamine units is superior, its name is chitosan. ${ }^{110}$ The molecular weight of chitosan may range from 300 to more than $1000 \mathrm{kDa}$, depending on its origin and preparation method. ${ }^{35}$ Chitosan is a semi-crystalline polymer and its crystallinity is dependent of the degree of deacetylation. ${ }^{107}$ The solubility of chitosan depends on the free amino and $\mathrm{N}$-acetyl groups, which are soluble in acidic $\mathrm{pH}^{35}$ The cationic nature of chitosan allows electrostatic interactions with anionic glycosaminoglycans (GAGs) and proteoglycans. Natural polymers are known to influence cell morphology, modulation, and differentiation, ${ }^{111,112}$ as referred to previously. This property is of crucial importance in the tissue engineering field, because GAG molecules modulate the action of several cytokines and growth factors. ${ }^{113}$

Chitosan presents a wide range of properties that make it appropriate for tissue engineering applications, namely, its biodegradability, ${ }^{89,114,115}$ biocompatibility, ${ }^{91,92,116}$ antibacterial activity, ${ }^{117-119}$ wound healing properties, ${ }^{120-123}$ and bioadhesive character. ${ }^{124}$

Chitosan can be hydrolyzed by chitosanases, ${ }^{125}$ which are absent in mammals. Lysozyme is responsible for the 
biodegradation of chitosan in vitro. ${ }^{89,126}$ The degradation rate of chitosan is inversely related to the degree of deacetylation, ${ }^{127}$ which represents the proportion of N-acetyl-Dglucosamine units to the total number of units. ${ }^{125}$ Lysozyme is ubiquitous in the human body. ${ }^{128}$ It is found in the lacrimal gland, middle ear, nose, bronchus, bronchiole, bone marrow, and digestive tract. ${ }^{129}$ Lysozyme has an important role in inflammatory response, being secreted by macrophages, monocytes, and granulocytes. ${ }^{130,131}$ Monocytes and macrophages are the main contributors to the presence of lysozyme in human serum in concentrations between 7 and $13 \mathrm{mg} / \mathrm{L} .{ }^{128}$

Chitosan has intrinsic anti-microbial properties against several microorganisms, namely, fungi and bacteria. ${ }^{132}$ The mechanism that results in these properties is unknown, although its cationic nature associates with anions in bacterial cell walls, suppressing biosynthesis and also disrupting the mass transport across the cell wall, leading to the death of bacteria. $^{132}$

Chitosan has been described as a potent wound-healing accelerator, ${ }^{133}$ and to possess immunological activity, by activating macrophages, ${ }^{134}$ to produce cytokines ${ }^{135}$ and to inhibit infection. . $^{136}$

One of the most important characteristics of chitosan, for tissue engineering applications, is its ability to be shaped into various structures, such as microspheres, ${ }_{137}^{137}$ paste, ${ }^{138}$ membranes, ${ }^{111}$ sponges, ${ }^{37,139-142}$ fibers, ${ }^{27,38,143}$ and porous scaffolds. ${ }^{25,27,54,144,145}$ Several processing methodologies have been used to produce porous chitosan scaffolds and will be discussed in detail in this article. Nevertheless, before describing scaffold processing techniques, it is important to underline the properties that a scaffold must possess to be successfully applied in bone tissue engineering applications.

\section{Scaffold Requirements for Bone Tissue Engineering}

Bone is a $3 \mathrm{D}$ tissue and cells alone do not grow in a $3 \mathrm{D}$ manner in vitro. For that reason, a tridimensional structure is required to support the formation of new functional bone tissue. This structure should provide a suitable environment for cell attachment, proliferation, differentiation, and ECM deposition. The in vitro cultured constructs, when implanted into the defect, must be vascularized and osteointegrated into the host bone. ${ }^{146}$ The 3D structures should be biocompatible, that is, not evoking an immune response when implanted in the host tissue. When a scaffold is implanted into the defect to restore bone functionality, it should activate the healing mechanisms (inflammatory response). The time course of healing is influenced by interactions between blood, scaffold surface, and degradation products, which are released from the scaffold and therefore, influencing biocompatibility. The ideal scaffold should degrade at a rate compatible with the rate of bone growth, physically creating open space for new bone formation, until full regeneration is achieved. The process of polymer degradation follows the mechanisms through which polymer chains are cleaved into oligomers and finally to monomers, which can be metabolized by natural mechanisms. ${ }^{147}$ If a biological process mediates the degradation process, it is designated as biodegradation. ${ }^{147}$ Several factors influence the kinetics of degradation: type of chemical bonds, $\mathrm{pH}$, polymer composition, crystallinity, molecular weight, porosity, water uptake, and anatomical location of the implant. ${ }^{147}$ Ideally, natural path- ways of the animal body should eliminate the degradation products.

As previously discussed, bone is a highly vascularized tissue relying on the interactions between bone cells and blood vessels. In this way, angiogenesis and neovascularization play a crucial role in bone repair, and should be taken into account when designing a scaffold. Angiogenesis is mainly characterized by the protrusion and outgrowth of capillary buds and sprouts from pre-existing blood vessels, whereas neovascularization comprises the formation of functional microvascular networks with red blood cell perfusion. ${ }^{148}$ Both processes are required to ensure successful engraftment of the construct into the surrounding host tissue. A vascular network can be included in a biodegradable and biocompatible scaffold by microfabrication techniques. ${ }^{149}$ The main property of the scaffold that is directly related to vascularization is its porosity. ${ }^{150}$ Scaffolds should have highly interconnected pores to promote cell ingrowth and distribution throughout the matrix, as well as facilitating the development of neovascularization. The minimum pore size is considered to be approximately $100-150 \mu \mathrm{m},{ }^{151}$ due to cell size, migration requirements, and fluid transport. However, due to vascularization requirement, pore sizes were shown to affect the course of osteogenesis. ${ }^{150}$ Large pores rapidly become well-vascularized, leading to direct osteogenesis. ${ }^{152,153}$ In contrast, small pores lead to hypoxic conditions, which tend to induce the development of an osteochondral process, before osteogenesis occurs. The porosity strongly influences scaffold mechanical properties. High porosity and pore size facilitates tissue ingrowth, but the consequence is a drastic reduction of mechanical properties, compromising the structural integrity of the scaffold. ${ }^{154}$ The mechanical properties of a scaffold should be compatible with those of the native tissue, maintaining its structural integrity after implantation. ${ }^{155}$ In general, the scaffold should be strong enough to not only resist stresses caused by the surrounding environment that may cause important dimensional changes. Scaffold integrity is critical, since cells and tissue remodeling are important to achieve a stable biomechanical environment and vascularization at the host site. The topography and surface chemistry of the scaffold play a crucial role in its performance, since those are the first elements that cells recognize when in contact with the scaffold surface. The hydrophilicity and hydrophobicity of the scaffold surface will modulate protein adsorption, which will in turn influence cell seeding. ${ }^{156}$

The methodology used to produce scaffolds for bone tissue engineering must not adversely affect biocompatibility or physical and chemical properties of the biomaterials used. Different scaffold batches may exhibit minor variations in their properties when prepared using the same parameters and conditions. ${ }^{157}$ Different processing methodologies for chitosan-based scaffolds have been already reported and will be further discussed in detail.

\section{Chitosan Scaffold Production Methods}

The most common methodology for producing chitosan scaffolds utilizes freeze-drying. This process consists of the lyophilization of a frozen chitosan solution, where the chitosan acetate salt is induced by the freezing conditions to phase-separate from the ice crystal phase. The ice phase is 
further sublimated, producing a porous structure. $^{24,35,37,49,54,142,145,154,158-169}$ In most cases, the scaffolds can still have chitosan acetate that will cause fast swelling and subsequently dissolution in a neutral aqueous medium. This can be overcome by cross-linking upon immersion in sodium hydroxide, ${ }^{35,163}$ sodium sulfate, $^{38}$ tripolyphosphate, ${ }^{37,142}$ ethanol series, ${ }^{35}$ or with a combination of crosslinking with rehydration. ${ }^{158}$ The freeze-drying technique requires very tight control of the temperature. If the temperature is not sufficiently low, the matrix will not become rigid enough to support the interfacial tension caused by the evaporation of the solvent without collapsing, creating a surface skin. Another limitation of the structures produced by this technique is that pore size is not very large. Also, the mechanical properties of the porous structures are very limited, even after cross-linking. Due to these limitations of freeze-drying, solvent-exchange/phase-separation has been proposed based on the gelation of a solution of chitosan using an alkaline solution below its gelation point. ${ }^{26,36,51,170}$ In a freeze-drying process the choice of the solvent is limited, since the solvent vapor pressure at the drying temperature (usually low) must be high enough to allow its removal. ${ }^{36}$ With this alternative method, which is also less time consuming and more economic, the choice of the solvent is wider. $^{36}$

Another processing methodology for chitosan is wet spinning, which allows the production of fibers. Due to the strong inter-chain forces derived from the hydroxyl and amino groups, chitosan tends to degrade at temperatures below its melting temperature, limiting its processability by melt or dry spinning methods. ${ }^{38,41,143,171-173}$ Basically, chitosan is dissolved in a solution of diluted acetic acid. This solution is spun through a spinneret into a coagulation bath, in this way producing fibers. Chitosan can also be processed by electrospinning into a nanofiber mesh scaffold. This method uses an electrical field created between a collector and a capillary connected to a reservoir with the polymer solution. The elongation of the drop of solution caused by the electrical field leads to the formation of very thin fibers with nanometer scale diameters. Electrospinning of pure chitosan $^{39,116,174-176}$ is considered to be quite difficult, since the resulting chitosan salt is soluble in water. Its stability in solution requires neutralization or cross-linking in a postprocessing stage that frequently has an impact on the morphology of the mesh. Several studies report the blending of chitosan with other polymers, being easier to process by electrospinning, namely silk fibroin, ${ }^{177}$ poly(ethylene oxide), ${ }^{178,179}$ poly(vinyl alcohol), ${ }^{180}$ collagen, ${ }^{181}$ or polycaprolactone. $^{182}$

Less conventional is the particle aggregation method (Fig. 1) proposed by Malafaya et al. ${ }^{23}$ This process relies on the bioadhesive character of chitosan that confers a strong bonding between individual particles. The scaffolds produced by this method have shown very interesting mechanical properties. In another study, chitosan-poly(lacticco-glycolic acid; PLAGA) microspheres were molded by mixing them with acetic acid solution in a stainless steel mold. ${ }^{183}$

Rapid prototyping may be another processing route enabling the manufacture of porous chitosan scaffolds. This methodology is based on the production of a 3D physical model from computer-aided design data (CAD software), which is generated in a layer-by-layer deposition process. ${ }^{144,184}$ Theoretically, a great variety of morphologies and shapes can be created by different variants of this technique resulting in reproducible geometry and mechanical properties.

Our group developed different chitosan-based scaffolds by melt-based routes. ${ }^{43,45}$ The vast majority of the processing methods used to produce chitosan scaffolds involve the use of solvents. Resident solvents are frequently toxic if they are entrapped be entrapped in a scaffold. We have developed various blends of chitosan with different aliphatic polyesters. Those blends can be processed by compression molding followed by salt leaching, ${ }^{43}$ melt spinning, and fiber bonding $^{27,45}$ into porous scaffolds with different morphologies and mechanical properties (Fig. 2).

A systematic list of various porous scaffold compositions using chitosan, the processing methods used to obtain scaffolds, and the in vitro evaluation with different cell types is provided in Table 1. It is clear from this table that the most used processing method to obtain chitosan-based porous scaffolds is freeze-drying or another freeze-related process. The main reason for this observation may be the simplicity of the process.

\section{In Vitro Cellular Approach in Bone Tissue Engineering}

The development of new scaffolds follows a typical evaluation routine. The first step is the assessment of potential cytotoxicity. This initial screening is based on the use of extracted leachables from the scaffold, that is, substances that

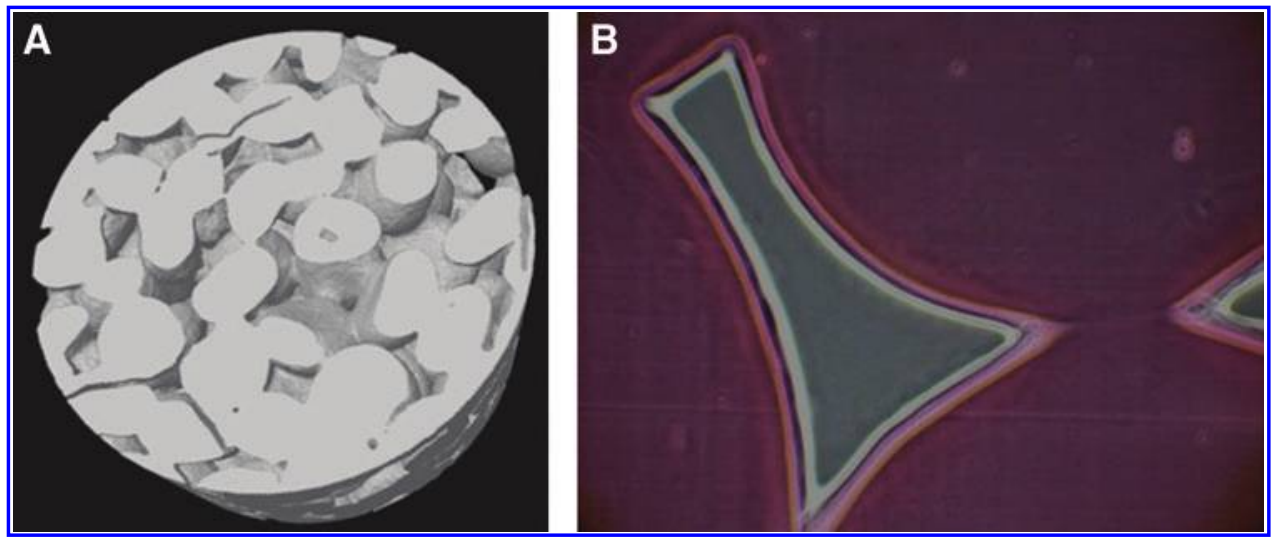

FIG. 1. Microcomputed tomography image of a cross section of chitosan scaffolds obtained by the particle aggregation method (A) and interface between the chitosan particles stained with eosin (B). Color images available online at www .liebertonline.com/teb 
FIG. 2. Chitosan-based scaffolds produced by compression molding followed by particle leaching (A) and fiber bonding (B) methodologies.

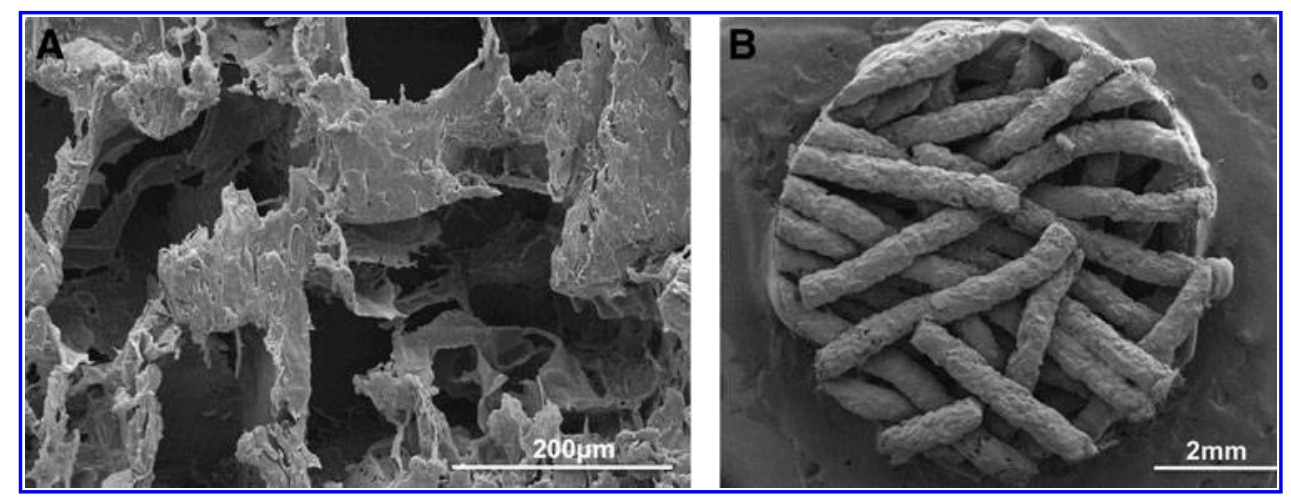

leach out of the biomaterials. These leachables are added in defined concentrations to standard culture medium and placed in contact with a cell line for a determined period. After this, cell viability and cell morphology are evaluated to determine the eventual toxicity to the cells. The use of cell lines is recommended in first stage testing, given that these cells are reproducible and can be expanded to large numbers. Cell lines, such as mouse fibroblast cells (L929) or human osteosarcoma cells (SAOS-2), are frequently used. If the scaffolds show no signs of cell cytotoxicity or morphology changes, the next step involves direct contact assays with an appropriate cell type to evaluate the cytocompatibility and phenotype functionality. A valid 3D construct for bone tissue engineering applications should have a positive outcome from this sequence of initial in vitro tests.

\section{Selection of cells}

Ideally, the cell source for scaffolds seeding should be nonimmunogenic, easily available, nontumorogenic, and with other defined and adequate characteristics. It should be expandable into large numbers and have demonstrated osteogenic potential. Autologous cells, from each patient, are preferred. ${ }^{185-189}$ These cells may be isolated from the biopsy of a patient's tissue (e.g., cartilage, bone, and skin) from the patient. The tissue obtained is dissociated and the isolated cells are expanded in culture for later implantation into the same patient. ${ }^{29,68,185}$ The use of autologous cells eliminates the risk of immune rejection and the need to use immunosuppressive drugs. For bone tissue engineering applications, osteoblasts are the most obvious selection, since those cells are responsible for the bone formation. ${ }^{72}$ However, these cells may have limited availability since the number of cells that are obtained after the isolation procedure is low and the expansion rate may be slow. ${ }^{190}$ In recent years stem cells have been studied as a viable alternative to isolated autologous cells. ${ }^{190}$ The term "stem cell" is used to describe undifferentiated cells with an ability to self-renew while maintaining the capacity for multi-lineage differentiation. ${ }^{63}$ There are primarily two types of stem cells that have been studied for tissue engineering applications, embryonic or adult. Embryonic stem cells (ESCs) are pluripotent cells derived from the inner cell mass of a blastocyst stage embryo. ${ }^{191}$ These cells possess long-term proliferation potential and are able to differentiate into all of the types of somatic cells in the organism. Ethical issues have been raised regarding the source of ESCs, which may limit their use in regenerative medicine. ASCs may be a valid alternative to ESCs in many applications. These cells can be isolated from different adult tissue sources such as bone marrow, ${ }^{63}$ peripheral blood, ${ }^{192}$ adipose tissue, ${ }^{193}$ or fetal tissues such as umbilical cord, ${ }^{194}$ amniotic fluid, ${ }^{195}$ or placenta. ${ }^{196}$ ASCs are multipotential cells capable of differentiating into several cell lineages such as osteoblasts, chondrocytes, and adipocytes. ${ }^{197}$ Recent reports sustain even a plasticity of ASCs, that is, their ability to be differentiated into other types of cells. ${ }^{198}$

The process of osteogenic differentiation of stem cells may be achieved by expanding the cells in standard culture medium, supplemented with $\beta$-glycerophosphate, ${ }^{199}$ ascorbic acid $^{200}$ and dexamethasone. ${ }^{65,200}$ These agents activate the osteogenic commitment of ASCs. Culture of osteogenic cells depends on the adequate supplementation of their growth medium with a source of inorganic phosphate, ${ }^{201} \beta$-glycerophosphate, a nonphysiological organic substrate of ALP, ${ }^{202}$ to produce mineralized ECM. Ascorbic acid is essential for the survival of human osteoblasts in vitro. ${ }^{203}$ This osteogenic inducing agent is required for collagen synthesis and ALP activity. ${ }^{200}$ Dexamethasone is a glucocorticoid that increases the expression of several genes associated with osteogenic differentiation. ${ }^{204}$ Moreover, the timing, size, and number of bone-like nodules is affected by the dose of dexamethasone used. ${ }^{205}$ Osteogenic medium can also be supplemented with growth factors that naturally occur in bone, such as bone morphogenic proteins (BMPs), fibroblast growth factors, platelet-derived growth factor (PDGF), transforming growth factor beta, and insulin growth factors. ${ }^{206-213}$ The process of osteogenic differentiation is coordinated and involves three main stages: (i) cell proliferation; (ii) ECM deposition and maturation; and (iii) mineralization. ${ }^{214}$ During cell proliferation, growth genes are expressed. ${ }^{215}$ Immediately after the downregulation of proliferation, the expression of ALP increases. ${ }^{214}$ During this period, the ECM undergoes a series of events that renders it competent for mineralization (ECM maturation and HA formation). ${ }^{215}$ After this stage, ECM becomes mineralized. ${ }^{214,215}$ With the onset of mineralization, the ECM protein genes become upregulated; for example, osteopontin and osteocalcin are increasingly expressed with the accumulation of mineralization. ${ }^{214}$ ALP activity before the onset of the mineralization suggests that this enzyme is involved in the preparation of ECM for mineral deposition. ${ }^{214}$ This enzyme is considered to be an early marker of osteogenic differentiation ${ }^{20,216,217}$ and used as an in vitro assessment of osteogenic differentiation. The mineral content of the bone ECM can be qualitatively assessed by alizarin red 
Table 1. Survey of IN Vitro Studies with Chitosan-Based Scaffolds Proposed in the Literature for Bone Tissue Engineering Applications

\begin{tabular}{|c|c|c|c|}
\hline Scaffold structure & Processing method & Cell type (source) & References \\
\hline Chitosan scaffolds & Freeze-drying & - & 35 \\
\hline Chitosan-TCP sponges & Freeze-drying & Fetal rat calvaria cells & 141 \\
\hline Chitosan-gelatin scaffolds & Freeze-drying & - & 157 \\
\hline Chitosan-TCP sponges & Freeze-drying & MG63 human cell line & 184 \\
\hline Chitosan-HA scaffolds & $\mathrm{RP}$ and freeze-drying & - & 143 \\
\hline Chitosan-calcium phosphate scaffolds & Freeze-drying & MG63 human cell line & 54 \\
\hline Chitosan scaffolds & Freeze gelation & ROS $17 / 2.8$ cells & 36 \\
\hline Chitosan sponges & Freeze-drying & Rat calvaria cells & 37 \\
\hline Chitosan fiber mesh scaffolds & Wet spinning & Human SAOS-2 cell line & 38 \\
\hline Chitosan scaffolds & Freeze-drying & MG63 human cell line & 158 \\
\hline Chitosan-silk scaffold & Freeze-drying & - & 49 \\
\hline Chitosan scaffolds & RP & Porcine BMSCs & 183 \\
\hline Chitosan scaffolds & Electrospinning & - & 39 \\
\hline Chitosan-gelatin scaffolds & Freeze-drying & HUVECs & 185 \\
\hline Chitosan scaffolds & Precipitation/Particle aggregation & ADAS & 23 \\
\hline Chitosan sponges & Freeze-drying & MG63 human cell line & 160 \\
\hline CPC-Chitosan scaffold & Cement/Particle leaching & MG63 human cell line & 186 \\
\hline Chitosan-starch scaffolds & Solvent-exchange phase separation & - & 46 \\
\hline Chitosan scaffolds with HA formation & Freeze-drying & Human SAOS-2 cell line & 162 \\
\hline Chitosan-nanoHA scaffolds & Freeze-drying & MC3T3-E1 cell line & 161 \\
\hline Chitosan-coralline scaffolds & Freeze-drying & CRL-12424 cell line & 163 \\
\hline HA-chitosan scaffold & Freeze-drying & Goat bone marrow cells & 24 \\
\hline Chitosan-gelatin scaffolds & Freeze gelation & Human BMSCs & 51 \\
\hline BCP-chitosan scaffolds & Freeze-drying & MC3T3-E1 cell line & 164 \\
\hline Chitosan-PLAGA scaffolds & Particle aggregation & MC3T3-E1 cell line & 42 \\
\hline $\begin{array}{l}\text { Chitosan gelatin/montmorillonite } \\
\text { scaffolds }\end{array}$ & Freeze-drying & Rat stromal cells TC1 & 165 \\
\hline Chitosan scaffolds & Freeze gelation & - & 40 \\
\hline Chitosan and chitosan-starch scaffolds & Freeze gelation & Human SAOS-2 cell line & 26 \\
\hline Chitosan-collagen sponges & Freeze-drying & Rat BMSCs & 166 \\
\hline Chitosan-PBS/PBTA/PCL & Compression molding/salt leaching & Mouse BMC-9 cell line & 25 \\
\hline Chitosan scaffolds & Wet spinning & Mouse osteoblast 7F2 cell line & 41 \\
\hline Chitosan-PBS scaffolds & Melt spinning/fiber bonding & Human BMSCs & 27 \\
\hline Chitosan-PBS/PCL/PBTA/PBSA & Compression molding/salt leaching & - & 43 \\
\hline Chitosan-PCL scaffolds & Electrospinning & MC3T3-E1 cell line & 181 \\
\hline Chitosan scaffolds & Freeze-drying & MC3T3-E1 cell line & 168 \\
\hline PLGA-chitosan scaffolds & Freeze-drying & Human BMSCs & 167 \\
\hline Chitosan sponges & Freeze-drying & Chicken embryo chondrocytes & 187 \\
\hline $\begin{array}{l}\text { Chitosan and chitosan-starch + lysozyme } \\
\text { scaffolds }\end{array}$ & Freeze gelation & Rat BMSCs & 188 \\
\hline PCL-chitosan & $\begin{array}{l}\text { Solvent casting/salt leaching/ } \\
\text { freeze drying }\end{array}$ & Rat osteoblasts & 44 \\
\hline
\end{tabular}

HA, hydroxyapatite; TCP, tricalcium phosphate; RP, rapid prototyping; PLLA, poly(L-lactic acid); ROS, rat ostosarcoma cells; HUVECs, human umbilical vein endothelial cells; ADAS, adipose-derived stem cells; CPC, calcium phosphate cement; $\mathrm{BCP}$, biphasic calcium phosphate; PLAGA, poly(lactic-co-acid-glycolic acid); PBS, poly(butylene succinate); PCL, polycaprolactone; PBTA, poly (butylene terephtalate adipate); PBSA, poly(butylene succinate adipate); PLGA, poly(L-glycolic acid); BMSCs, bone marrow mesenchymal stem cells.

or von Kossa staining, and the calcium content can be quantitatively assessed. This information can be complemented by the analysis of the mineral fraction by energy dispersive spectroscopy, which detects the presence of calcium and phosphorous elements. Thin-film X-ray diffraction may be used to analyze the crystallinity of the ECM. Fouriertransformed spectroscopy may be used to detect carbonate and phosphate groups. ${ }^{27,218}$

\section{In vitro studies with chitosan as a biomaterial}

It is well accepted that cells strongly interact with their environment, namely, with neighboring cells, ECM, and the surface to which they adhere. ${ }^{219}$ Chitosan as a biomaterial as previously mentioned has an analogous structure to the GAGs present in connective tissue ECM. Several studies describe the positive influence of chitosan on cell attachment, proliferation, and the osteogenic differentiation of MSCs (Table 1). Mouse MSCs in contact with a chitosan suspension were shown to improve osteogenic differentiation, when compared to cells seeded onto polystyrene culture wells. ${ }^{220}$ Lahiji et al. reported that chitosan-coated coverslips are an appropriate substrate for the growth of human osteoblasts and chondrocytes. ${ }^{108}$ Poly(D,L-lactic acid) films modified with chitosan solution improved cell adhesion, proliferation, and biosynthetic activity, using human osteoblasts. ${ }^{221}$ Moreover, neonatal rat calvaria osteoblasts proliferate at superior rates on titanium surfaces coated with chitosan compared with titanium alone. ${ }^{222}$ In fact, 
coating of titanium pins with chitosan induced minimal inflammatory response and a positive healing of a rabbit tibial defect. $^{223}$ MC3T3-E1 osteoblast-like cells proliferated and increased ALP activity, as well as upregulation of osteogenic gene expression, in composite chitosan/PLAGA scaffolds as compared to PLAGA scaffolds. ${ }^{183}$ Chitosan-collagen sponges with higher concentration of chitosan positively promoted osteoblastic differentiation of bone marrow mesenchymal stem cells (BMSCs) and improved the mechanical and physical properties of the matrices. ${ }^{167}$ Previous studies from our group, using flat discs obtained by injection molding composed of chitosan-poly(butylene succinate) (PBS) and PBS blends, showed that chitosan had a positive effect on osteoblast-like cells. $^{224}$ Further, two groups reported that PCL nanofibrous scaffolds containing chitosan revealed that stem cells adhered, proliferated, and expressed phenotypic markers of osteogenic differentiation in a superior way compared to nanofibrous scaffolds alone. ${ }^{182,225}$ The ability of chitosan to support cell adhesion and influence osteogenic differentiation of cells can be attributed to its chemical properties.

In vitro testing systems are inevitably limited in their capacity to recreate the complex in vivo environment. Therefore, these tests may be unable to accurately predict in vivo performance, particularly in the context of tissue engineering and regeneration of functional tissues. Thus, in later stages of the development of a tissue engineering strategy, it may be critical to include in vivo experiments.

\section{In Vivo Animal Models}

The general trend in bone tissue engineering after successful in vitro testing of the constructs is to implant the in vitro tissue-engineered construct in a relevant animal model. Often, an ectopic small animal model (e.g., mouse or rat) is first. Constructs are implanted into a nonbone anatomic location of the animal's body. ${ }^{88,226-228}$ Those areas can be intraperitoneal, intramuscular, mesenteric, or subcutaneous. These models are also useful in determining whether a scaffold has adequate properties, for example, sufficient porosity and pore interconnectivity to allow tissue ingrowth and neovascularization. It is important to determine the biodegradation of implant materials, in terms of both degradation products and the host immune response. If the aim is to use human cells, nude mouse/rat models are commonly used. These models can be used to screen tissue-engineered constructs for osteoconductivity (i.e., the ability of the scaffold to induce proliferation of undifferentiated stem cells), the differentiation of seeded cells to an osteogenic lineage, and the formation of ectopic bone. ${ }^{229-232}$

An in vivo approach should mimic the clinical situation closely as possible. Some models use an intraosseous wound that will not heal spontaneously (i.e., critical-sized defect). ${ }^{81}$ The minimum size of a critical-sized defect is not absolutely clear. This is a complex situation as a defect cannot be defined only by size; it is dependent on other variables (e.g., other species and anatomic location). ${ }^{233}$ Guidelines are available for the dimensions of implants based on the size of the animal, bone chosen, and an implant design that avoids pathological fracture. ${ }^{234}$ It is important to include controls in the experimental design. These controls should be of a material already in clinical use and also a control consisting of an empty defect, to prove that the bone defect is not able to regenerate itself. $^{234}$ There are several types of bone defects that can be used, such as cranial, segmental, partially cortical, and cancellous bone. These locations can be subjected to load or nonload bearing (e.g., femur or calvarial, respectively). The type of animal can be small (mouse or rat) $88,102,213,235,236$ or large (rabbit, sheep, goat, dog, or nonhuman primates). ${ }^{140,185,237-242}$ Typically, researchers start with a smaller model that is less costly and where the experimental results may be easy to compare with many other experiments reported in the literature. One of the most accepted nonloading bearing models is the calvaria bone defect. This flat bone allows the creation of a uniform circular defect, and has sufficient size to make easy surgical procedure and handling in small animals. In those models, the dura mater and the overlying skin provide fixation of the scaffold. The model has been systematically studied and is very well established. ${ }^{81,82,243,244}$ This model can be performed in small animals using rat re,246 $^{24 \text { mouse. }}$ or $^{213,235}$ It can be also applied to large animals, like rabbit ${ }^{247-249}$ or sheep. ${ }^{189}$

The last stage of preclinical trials of a bone tissue engineering strategy should be performed in animals that are believed to be more similar to humans, in terms of metabolism, physiology, anatomy, etc. Bones of small animals are more reactive to specific stimuli and are not subjected to comparable stresses. For example, a femur defect in rats $^{250-252}$ is believed to heal faster that in larger animals. ${ }^{243}$ However, in a study where the authors compared the bone ingrowth using the same chamber, in rats and in goats, no significant differences were observed between the two animals. ${ }^{253}$ In vivo experimental design is therefore not an easy task. It is necessary to balance all the variables and decide which animal model suits better the specific goals of the experiment. Surgeries involving load-bearing conditions and perhaps requiring stabilization with internal or external fixation devices command a high level of surgical expertise. The maintenance of large mammals can be expensive. It is often useful to limit the number of experimental variables to reduce random effects and to ensure as much statistical significance as possible. Variables such as physical condition of the animal (nutritional status, diet, age, and sex); administration of anesthesics and/or analgesics; type of bone defect (anatomic location or use of fixation devices); and methodologies used to assess sample collection and characterization may influence the final outcome. Despite these issues, preclinical tests should be performed in large animals. Sheep or goat, for example, has a metabolism, weight, and a bone remodeling rate similar to humans. $12,18,186,189,239$

\section{In vivo bone regeneration studies with chitosan material}

As described above, chitosan is already used in medicine as a biomaterial for wound dressings. However, there are several reports in the literature showing the ability of chitosan to be used as material to regenerate bone (Table 2). The first report describing an attempt to regenerate bone in vivo using chitosan dates to $1988,{ }^{111}$ when Muzzarelli and colleagues implanted chitosan membranes and chitosan ascorbate gel into cranial defects in cats. Their findings suggested that chitosan seems to induce a stimulatory and/or attractive effect on stromal cells of surrounding tissues. Subsequent studies from the same authors describe the use of methylpirrolidone 


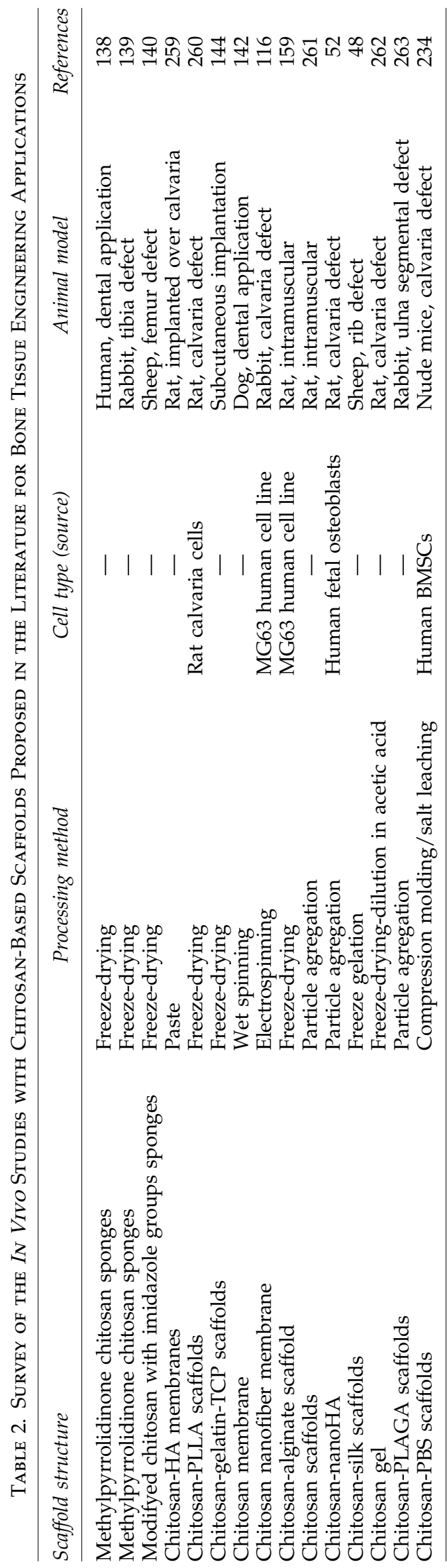

chitosan in defects created in the rabbit tibia ${ }^{140}$ and in the sheep femoral head. ${ }^{141}$ These studies confirmed previous observations ${ }^{111}$ of the possible stimulatory and/or attractive effect of chitosan on adjacent cells. Chitosan has also been used as carrier for growth factors, such as PDGF-BB, to promote bone formation in a critical-sized calvaria defect in rats. ${ }^{208,254}$ Osteoconductive chitosan/tricalcium phosphate (TCP) sponges were observed to promote osseous healing of rat calvarial defects versus controls (without scaffolds). The addition of PDGF-BB to a carrier further enhanced bone regeneration. ${ }^{254}$ These authors observed that chitosan/TCP sponges without bioactive PDGF-BB resulted in more bone formation in these versus chitosan-TCP without the bioactive agents. ${ }^{208}$ PDGF growth factor is produced by platelets, osteoblasts, and monocytes/macrophages and it is believed to have a role in the migration of MSCs to wound sites. ${ }^{255}$ The combination of chitosan-PBS scaffolds with human BMSCs implanted into critical-sized cranial defects in nude mice resulted in enhanced integration with the surrounding tissue and significant bone formation. This was more evident for the scaffolds cultured with human cells. ${ }^{232}$ Electrospun chitosan nanofiber membranes evidenced new bone formation at 4 weeks in rabbit cranial defects compared to the controls (empty bone defects), where only soft tissue formation was observed. ${ }^{116}$ Chitosan combined with nanoHA, in the form of microspheres, implanted in rat calvaria defects for 12 weeks were observed to promote bone regeneration. ${ }^{52}$ Moreover, chitosan-PLAGA microspheres conjugated in a scaffold by particle aggregation, with or without heparin and recombinant human bone morphogenetic protein 2 (rhBMP-2), promoted bone regeneration in vivo, with more pronounced results for the scaffolds with the incorporated growth factor. ${ }^{256}$ A study by Ríos and coworkers ${ }^{48}$ used a model mimicking the clinical bone free flaps, by using a cranial flap that involves the design of the desired tissue at an ectopic site in the patient's own body. This study used chambers containing silk fibroin-chitosan scaffolds implanted on top of the grafted periosteum over the latissimus dorsi muscle of sheep. ${ }^{48}$ Bone grafts were used as positive controls and empty defects as negative controls. The authors found that the same amount of bone was regenerated in the defects with the tested scaffolds, as for the defects with bone grafts. ${ }^{48}$

\section{Conclusions and Final Remarks}

Recent developments in bone tissue engineering have been considerable, but as yet there are no bone tissueengineered products in widespread clinical use. Both cells and biomaterial components need to be optimized to produce a functional bone tissue-engineered therapy.

New stem cell sources are being explored, such as extraembryonic tissues, placenta, amniotic fluid, and umbilical cord. These stem cells have been shown to express pluripotent markers and low immunogenicity, evidencing a more primitive state. These cells are often discarded, which makes these sources attractive candidates for tissue engineering applications. Moreover, their low immunogenic potential could enable the use of these cells as an allogenic cell source for successful bone repair.

A new generation of biodegradable natural biomaterials is emerging, with chitosan being one of the most interesting. Chitosan has been extensively studied as a biomaterial for 
bone tissue engineering scaffolds, but in practice it is still and only used as a wound dressing and hemostatic agent in medicine. Several morphologies can be successfully obtained by different processing techniques, which make this material attractive for producing scaffolds. Several studies report the biological enhancement of scaffolds with the addition of chitosan and its influence over osteogenic differentiation and bone regeneration; however, the mechanism of action remains unclear. It is worthwhile to continue to pursue research with this interesting natural polymer to clarify its function over cell performance, as well as, to improve scaffold manufacturing methodologies that could lead to its clinical use in the bone regeneration field.

\section{Acknowledgments}

This review was supported by the FCT grant (SFRH/ $24735 / 2005)$ to Ana Costa-Pinto. The authors also want to acknowledge the precious help of Ana M. Martins in the revision of the article.

\section{Disclosure Statement}

No competing financial interests exist.

\section{References}

1. Muschler, G.F., Negami, S., Hyodo, A., Gaisser, D., Easley, K., and Kambic, H. Evaluation of collagen ceramic composite graft materials in a spinal fusion model. Clin Orthop Relat Res 328, 250, 1996.

2. Lewandrowski, K.-U., Gresser, J., Wise, D.L., and Trantolo, D.J. Bioresorbable bone graft substitutes of different osteoconductivities: a histologic evaluation of osteointegration of poly(propylene glycol-co-fumaric acid)-based cement implants in rats. Biomaterials 21, 757, 2000.

3. Desai, B. Osteobiologics. Am J Orthop 36, 8, 2007.

4. Muramatsu, K., Doi, K., Ihara, K., Shigetomi, M., and Kawai, S. Recalcitrant posttraumatic nonunion of the humerus: 23 patients reconstructed with vascularized bone graft: 23 patients reconstructed with vascularized bone graft. Acta Orthop Scand 74, 952003.

5. Al-Sayyad, M., and Abdulmajeed, T. Fracture of the anterior iliac crest following autogenous bone grafting. Saudi Med J 27, 254, 2006.

6. Pritsch, T., Bickels, J., Wu, C.-C., Squires, H., and Malawer, $\mathrm{M}$. The risk for fractures after curettage and cryosurgery around the knee. Clin Orthop Relat Res 458, 159, 2007.

7. Chen, Y.-C., Chen, C.-H., Chen, P.-L., Huang, I.-Y., Shen, Y.-S., and Chen, C.-M. Donor site morbidity after harvesting of proximal tibia bone. Head Neck 28, 496, 2006.

8. Chou, L., Mann, R., Coughlin, M., Mcpeake, W., and Mizel, M. Stress fracture as a complication of autogenous bone graft harvest from the distal tibia. Baltimore: Williams Wilkins, 2007.

9. Laurencin, C., Khan, Y., and El-Amin, S.F. Bone graft substitutes. Expert Rev Med Devices 3, 49, 2005.

10. Ilizarov, G. The tension-stress effect on the genesis and growth of tissues: part I. The influence of stability of fixation and soft-tissue preservation. Clin Orthop Relat Res 238, 249, 1989.

11. Perka, C., Schultz, O., Spitzer, R.-S., Lindenhayn, K., Burmester, G.-R., and Sittinger, M. Segmental bone repair by tissue-engineered periosteal cell transplants with bior- esorbable fleece and fibrin scaffolds in rabbits. Biomaterials 21, 1145, 2000.

12. Gugala, Z., and Gogolewski, S. Healing of critical-size segmental bone defects in the sheep tibiae using bioresorbable polylactide membranes. Injury 33, 71, 2002.

13. Cook, S.D., Salkeld, S.L., Brinker, M.R., Wolfe, M.W., and Rueger, D.S. Use of an osteoinductive biomaterial (rHOP-1) in healing of segmental bone defects. J Orthop Trauma 12, 40, 1998.

14. Langer, R., and Vacanti, J. Tissue engineering. Science 260, 920, 1993.

15. Hutmacher, D.W. Scaffolds in tissue engineering bone and cartilage. Biomaterials 21, 2529, 2000.

16. Hutmacher, D.W., Schantz, J.T., Lam, C.X.F., Tan, K.C., and Lim, T.C. State of the art and future directions of scaffoldbased bone engineering from a biomaterials perspective. J Tissue Eng Regen Med 1, 245, 2007.

17. Bonfield, W. Designing porous scaffolds for tissue engineering. Phil Trans R Soc 364, 227, 2006.

18. Mendes, S., Reis, R., Bovell, Y., Cunha, A., Van Blitterswijk, C.A., and de Bruijn, J. Biocompatibility testing of novel starchbased materials with potential application in orthopaedic surgery: a preliminary study. Biomaterials 22, 2057, 2001.

19. Salgado, A., Gomes, M., Chou, A., Coutinho, O., Reis, R., and Hutmacher, D. Preliminary study on the adhesion and proliferation of human osteoblasts on starch-based scaffolds. Mater Sci Eng C 20, 27, 2002.

20. Gomes, M., Sikavitsas, V., Behravesh, E., Reis, R., and Mikos, A. Effect of flow perfusion on the osteogenic differentiation of bone marrow stromal cells cultured on starch-based threedimensional scaffolds. J Biomed Mater Res 67A, 87, 2003.

21. Salgado, A., Coutinho, O., and Reis, R. Novel starch-based scaffolds for bone tissue engineering: cytotoxicity, cell culture, and protein expression. Tissue Eng 10, 465, 2004.

22. Gomes, M.E., Godinho, J.S., Tchalamov, D., Cunha, A.M., and Reis, R.L. Alternative tissue engineering scaffolds based on starch: processing methodologies, morphology, degradation and mechanical properties. Mater Sci Eng C 20, 19, 2002.

23. Malafaya, P., Pedro, A., Peterbauer, A., Gabriel, C., Redl, H., and Reis, R.L. Chitosan particles agglomerated scaffolds for cartilage and osteochondral tissue engineering approaches with adipose tissue derived stem cells. I Mater Sci Mater Med 16, 1077, 2005.

24. Oliveira, J., Rodrigues, M., Silva, S., Malafaya, P., Gomes, M., Viegas, C., Dias, I., Azevedo, J., Mano, J., and Reis, R.L. Novel hydroxyapatite/chitosan bilayered scaffold for osteochondral tissue-engineering applications: scaffold design and its performance when seeded with goat bone marrow stromal cells. Biomaterials 27, 6123, 2006.

25. Costa-Pinto, A., Correlo, V., Sol, P., Bhattacharya, M., Charbord, P., Delorme, B., Reis, R., and Neves, N. Adhesion, proliferation, and osteogenic differentiation of a mouse mesenchymal stem cell line (BMC9) seeded on novel melt-based chitosan/polyester 3D porous scaffolds. Tissue Eng 14, 1049, 2008.

26. Martins, A., Santos, M., Azevedo, H., Malafaya, P., and Reis, R. Natural origin scaffolds with in situ pore forming capability for bone tissue engineering applications. Acta Biomater 4, 1637, 2008.

27. Costa-Pinto, A., Correlo, V., Sol, P., Bhattacharya, M., Charbord, P., Delorme, B., Reis, R., and Neves, N. Osteogenic differentiation of human bone marrow mesenchymal stem cells seeded on melt based chitosan scaffolds for bone tissue engineering applications. Biomacromolecules 10, 2067, 2009. 
28. Oliveira, J., Santos, T., Martins, L., Picciochi, R., Marques, A., Castro, A., Neves, N., Mano, J., and Reis, R. Gellan gum injectable hydrogels for cartilage tissue engineering applications: in vitro studies and preliminary in vivo evaluation. Tissue Eng Part A 16, 343, 2010.

29. Oliveira, J., Gardel, L., Rada, T., Martins, L., Gomes, M., and Reis, R. Injectable gellan gum hydrogels with autologous cells for the treatment of rabbit articular cartilage defects. J Orthop Res 28, 1193, 2010.

30. Oliveira, J.T., Martins, L., Picciochi, R., Malafaya, P.B., Sousa, R.A., Neves, N.M., Mano, J.F., and Reis, R.L. Gellan gum: a new biomaterial for cartilage tissue engineering applications. J Biomed Mater Res Part A 93A, 852, 2010.

31. Silva, N.A., Salgado, A.J., Sousa, R.A., Oliveira, J.T., Pedro, A.J., Leite-Almeida, H., Cerqueira, R., Almeida, A., Mastronardi, F., Mano, J.F., Neves, N.M., Sousa, N., and Reis, R.L. Development and characterization of a novel hybrid tissue engineering based scaffold for spinal cord injury repair. Tissue Eng Part A 16, 45, 2010.

32. Silva, S.S., Santos, M.I., Coutinho, O.P., Mano, J.F., and Reis, R.L. Physical properties and biocompatibility of chitosan/soy blended membranes. J Mater Sci Mater Med 16, 575, 2005.

33. Silva, S.S., Maniglio, D., Motta, A., Mano, J.F., Reis, R.L., and Migliaresi, C. Genipin-modified silk-fibroin nanometric nets. Macromol Biosci 8, 766, 2008.

34. Silva, S.S., Motta, A., Rodrigues, M.T., Pinheiro, A.F.M., Gomes, M.E., Mano, J.F., Reis, R.L., and Migliaresi, C. Novel genipin-cross-linked chitosan/silk fibroin sponges for cartilage engineering strategies. Biomacromolecules $\mathbf{9}$, 2764, 2008

35. Madihally, S. Porous chitosan scaffolds for tissue engineering. Biomaterials 20, 1133, 1999.

36. Ho, M.H., Kuo, P.Y., Hsieh, H.J., Hsien, T.Y., Hou, L.T., Lai, J.Y., and Wang, D.M. Preparation of porous scaffolds by using freeze-extraction and freeze-gelation methods. Biomaterials 25, 129, 2004.

37. Seol, Y.J., Lee, J.Y., Park, Y.J., Lee, Y.M., Young, K., Rhyu, I.C., Lee, S.J., Han, S.B., and Chung, C.P. Chitosan sponges as tissue engineering scaffolds for bone formation. Biotechnol Lett 26, 1037, 2004.

38. Tuzlakoglu, K., Alves, C.M., Mano, J.F., and Reis, R.L. Production and characterization of chitosan fibers and 3-D fiber mesh scaffolds for tissue engineering applications. Macromol Biosci 4, 811, 2004.

39. Geng, X., Kwon, O.-H., and Jang, J. Electrospinning of chitosan dissolved in concentrated acetic acid solution. Biomaterials 26, 5427, 2005.

40. Hsieh, C.-Y., Tsai, S.-P., Ho, M.-H., Wang, D.-M., Liu, C.-E., Hsieh, C.-H., Tseng, H.-C., and Hsieh, H.-J. Analysis of freeze-gelation and cross-linking processes for preparing porous chitosan scaffolds. Carbohydr Polymers 67, 124, 2007.

41. Heinemann, C., Heinemann, S., Bernhardt, A., Worch, H., and Hanke, T. Novel textile chitosan scaffolds promote spreading, proliferation, and differentiation of osteoblasts. Biomacromolecules 9, 2913, 2008.

42. Abdel-Fattah, W.I., Jiang, T., El-Bassyouni, G.E.-T., and Laurencin, C.T. Synthesis, characterization of chitosans and fabrication of sintered chitosan microsphere matrices for bone tissue engineering. Acta Biomater 3, 503, 2007.

43. Correlo, V., Boesel, L., Pinho, E., Costa-Pinto, A., Alves da Silva, M., Bhattacharya, M., Mano, J., Neves, N., and Reis, R. Melt-based compression-molded scaffolds from chitosan- polyester blends and composites: morphology and mechanical properties. J Biomed Mater Res A 91A, 498, 2009.

44. Wu, H., Wan, Y., Dalai, S., and Zhang, R. Response of rat osteoblasts to polycaprolactone/chitosan blend porous scaffolds. J Biomed Mater Res Part A 92A, 238, 2009.

45. Correlo, V.M., Costa-Pinto, A.R., Sol, P., Covas, J.A., Bhattacharya, M., Neves, N.M., and Reis, R.L. Melt processing of chitosan-based fibers and fiber-mesh scaffolds for the engineering of connective tissues. Macromol Biosci 10, 1495, 2010.

46. Nakamatsu, J., Torres, F.G., Troncoso, O.P., Min-Lin, Y., and Boccaccini, A.R. Processing and characterization of porous structures from chitosan and starch for tissue engineering scaffolds. Biomacromolecules 7, 3345, 2006.

47. Baran, E.T., Mano, J.F., and Reis, R.L. Starch-chitosan hydrogels prepared by reductive alkylation cross-linking. J Mater Sci Mater Med 15, 759, 2004.

48. Ríos, C.N., Skoracki, R.J., Miller, M.J., Satterfield, W.C., and Mathur, A.B. In vivo bone formation in silk fibroin and chitosan blend scaffolds via ectopically grafted periosteum as a cell source: a pilot study. Tissue Eng Part A 15, 2717, 2009.

49. Gobin, A.S., Froude, V.E., and Mathur, A.B. Structural and mechanical characteristics of silk fibroin and chitosan blend scaffolds for tissue regeneration. J Biomed Mater Res A 74, 465, 2005.

50. Manjubala, I., Woesz, A., Pilz, C., Rumpler, M., FratzlZelman, N., Roschger, P., Stampfl, J., and Fratzl, P. Biomimetic mineral-organic composite scaffolds with controlled internal architecture. J Mater Sci: Mater Med 16, 1111, 2005.

51. Zhao, F., Grayson, W.L., Ma, T., Bunnell, B., and Lu, W.W. Effects of hydroxyapatite in 3-D chitosan-gelatin polymer network on human mesenchymal stem cell construct development. Biomaterials 27, 1859, 2006.

52. Chesnutt, B.M., Yuan, Y., Buddington, K., Haggard, W.O., and Bumgardner, J.D. Composite chitosan/nanohydroxyapatite scaffolds induce osteocalcin production by osteoblasts in vitro and support bone formation in vivo. Tissue Eng Part A 15, 2571, 2009.

53. Finisie, M.R., Josue, A., Favere, V.T., and Laranjeira, M.C. Synthesis of calcium-phosphate and chitosan bioceramics for bone regeneration. An Acad Bras Cienc 73, 525, 2001.

54. Zhang, Y., Ni, M., Zhang, M., and Ratner, B. Calcium phosphate-chitosan composite scaffolds for bone tissue engineering. Tissue Eng 9, 337, 2003.

55. Xu, H.H., Takagi, S., Quinn, J.B., and Chow, L.C. Fastsetting calcium phosphate scaffolds with tailored macropore formation rates for bone regeneration. J Biomed Mater Res A 68, 725, 2004.

56. Correlo, V.M., Boesel, L.F., Bhattacharya, M., Mano, J.F., Neves, N.M., and Reis, R.L. Hydroxyapatite reinforced chitosan and polyester blends for biomedical applications. Macromol Mater Eng 290, 1157, 2005.

57. Zhang, Y., Xu, H.H., Takagi, S., and Chow, L.C. In-situ hardening hydroxyapatite-based scaffold for bone repair. I Mater Sci Mater Med 17, 437, 2006.

58. Mukherjee, D.P., Tunkle, A.S., Roberts, R.A., Clavenna, A., Rogers, S., and Smith, D. An animal evaluation of a paste of chitosan glutamate and hydroxyapatite as a synthetic bone graft material. J Biomed Mater Res B Appl Biomater 67, 603, 2003.

59. Rodan, G.A. Introduction to bone biology. Bone 13, S3, 1992.

60. Weiner, S., and Wagner, H. The material bone: structure mechanical function relations. Annu Rev Mater Sci 28, 271, 1998. 
61. Jee, W. Integrated bone tissue physiology: anatomy and physiology. In: Cowin, S.C., ed. Bone Mechanics Handbook, 2nd edition. Boca Raton: CRC press, 2001, p. 1.

62. Friedenstein, A., Deriglasova, U., Kulagina, N., Panasuk, A., Rudakowa, S., Luriá, E., and Ruadkow, I. Precursors for fibroblasts in different populations of hematopoietic cells as detected by the in vitro colony assay method. Exp Hematol 2, 83, 1974.

63. Owen, M. Marrow stromal stem cells. J Cell Sci 10 (Suppl), 63, 1988.

64. Simmons, P., and Torok-Storb, B. CD34 Expression by stromal precursors in normal human adult bone marrow. Blood 11, 2848, 1991.

65. Haynesworth, S.E., Goshima, J., Goldberg, V.M., and Caplan, A.I. Characterization of cells with osteogenic potential from human marrow. Bone 13, 81, 1992.

66. Nakahara, H., Goldberg, V.M., and Caplan, A.I. Cultureexpanded human periosteal-derived cells exhibit osteochondral potential in vivo. J Orthop Res 9, 465, 1991.

67. Bianco, P., Riminucci, M., Gronthos, S., and Robey, P.G. Bone marrow stromal stem cells: nature, biology, and potential applications. Stem cells 19, 180, 2001.

68. Quarto, R., Mastrogiacomo, M., Cancedda, R., Kutepov, S., Mukhaev, V., Lakroukov, A., Kon, E., and Marcacci, M. Repair of large bone defects with the use of autologous bone marrow stromal cells. N Engl J Med 344, 385, 2001.

69. Marcacci, M., Kon, E., Moukhachev, V., Lavroukov, A., Kutepov, S., Quarto, R., Mastrogiacomo, M., and Cancedda, R. Stem cells associated with macroporous bioceramics for long bone repair: 6- to 7-year outcome of a pilot clinical study. Tissue Eng 13, 947, 2007.

70. Calvi, L.M., Adams, G.B., Weibrecht, K.W., Weber, J.M., Olson, D.P., Knight, M.C., Martin, R.P., Schipani, E., Divieti, P., Bringhurst, F.R., Milner, L.A., Kronenberg, H.M., and Scadden, D.T. Osteoblastic cells regulate the haematopoietic stem cell niche. Nature 425, 841, 2003.

71. Zhang, J., Niu, C., Ye, L., Huang, H., He, X., Tong, W.-G., Ross, J., Haug, J., Johnson, T., Feng, J.Q., Harris, S., Wiedemann, L.M., Mishina, Y., and Li, L. Identification of the haematopoietic stem cell niche and control of the niche size. Nature 425, 836, 2003.

72. Robey, P., and Termine, J. Human bone cells in vitro. Calcif Tissue Int 37, 453, 1985.

73. Fuchs, S., Hofmann, A., and Kirkpatrick, C.J. Microvessellike structures from outgrowth endothelial cells from human peripheral blood in 2-dimensional and 3-dimensional co-cultures with osteoblastic lineage cells. Tissue Eng 13, 2577, 2007.

74. Unger, R.E., Sartoris, A., Peters, K., Motta, A., Migliaresi, C., Kunkel, M., Bulnheim, U., Rychly, J., and James Kirkpatrick, C. Tissue-like self-assembly in cocultures of endothelial cells and osteoblasts and the formation of microcapillary-like structures on three-dimensional porous biomaterials. Biomaterials 28, 3965, 2007.

75. Santos, M.I., Unger, R.E., Sousa, R.A., Reis, R.L., and Kirkpatrick, C.J. Crosstalk between osteoblasts and endothelial cells co-cultured on a polycaprolactone-starch scaffold and the in vitro development of vascularization. Biomaterials 30, 4407, 2009.

76. Nomura, S., and Takano-Yamamoto, T. Molecular events caused by mechanical stress in bone. Matrix Biol 19, 91, 2000.

77. Kronenberg, H.M. Developmental regulation of the growth plate. Nature 423, 332, 2003.
78. Horton, W. The biology of bone growth. Growth Genet Horm 6, 1, 1990.

79. Bruder, S., and Caplan, A. Cellular and molecular events during embryonic bone development. Connect Tissue Res 20, 65, 1989.

80. Bianco, P., Cancedda, F., Riminucci, M., and Cancedda, R. Bone formation via cartilage models: the "borderline" chondrocyte. Matrix Biol 17, 185, 1998.

81. Schmitz, J., and Hollinger, J. The critical size defect as an experimental model for craniomandibulofacial nonunions. Clin Orthop Relat Res 205, 299, 1986.

82. Hollinger, J.O., and Kleinschmidt, J.C. The critical size defect as an experimental model to test bone repair materials. J Craniofac Surg 1, 60, 1990.

83. Aaboe, M., Pinholt, E., and Hjorting-Hansen, E. Healing of experimentally created defects: a review. Br J Oral Maxillofac Surg 33, 312, 1995.

84. Pham, Q.P., Kurtis Kasper, F., Scott Baggett, L., Raphael, R.M., Jansen, J.A., and Mikos, A.G. The influence of an in vitro generated bone-like extracellular matrix on osteoblastic gene expression of marrow stromal cells. Biomaterials 29, 2729, 2008.

85. Kaplan, D. Biopolymers from renewable resources. New York: Springer, 1998.

86. Azevedo, H.S., Gama, F.M., and Reis, R.L. In vitro assessment of the enzymatic degradation of several starch based biomaterials. Biomacromolecules 4, 1703, 2003.

87. Mendes, S.C., Bezemer, J., Claase, M.B., Grijpma, D.W., Bellia, G., Degli-Innocenti, F., Reis, R.L., De Groot, K., Van Blitterswijk, C.A., and De Bruijn, J.D. Evaluation of two biodegradable polymeric systems as substrates for bone tissue engineering. Tissue Eng 9, S91, 2003.

88. Salgado, A., Coutinho, O., Reis, R., and Davies, J. In vivo response to starch-based scaffolds designed for bone tissue engineering applications. J Biomed Mater Res A 80, 983, 2006.

89. Tomihata, K., and Ikada, Y. In vitro and in tivo degradation of films of chitin and its deacetylated derivatives. Biomaterials 18, 261, 1997.

90. Varum, K., Myhr, M., Hjerde, R., and Smidsrod, O. In vitro degradation rates of partially $\mathrm{N}$-acetylated chitosans in human serum. Carbohydr Res 299, 99, 1997.

91. Molinaro, G., Leroux, J.C., Damas, J., and Adam, A. Biocompatibility of thermosensitive chitosan-based hydrogels: an in vivo experimental approach to injectable biomaterials. Biomaterials 23, 2717, 2002.

92. Rucker, M., Laschke, M.W., Junker, D., Carvalho, C., Schramm, A., Mulhaupt, R., Gellrich, N.C., and Menger, M.D. Angiogenic and inflammatory response to biodegradable scaffolds in dorsal skinfold chambers of mice. Biomaterials 27, 5027, 2006.

93. Xiao, Y., Young, W.G., and Bartold, P.M. Tissue engineering for bone regeneration using osteoblasts in collagen scaffolds. J Dent Res 81, 0851, 2002.

94. Sachlos, E., Reis, N., Ainsley, C., Derby, B., and Czernuszka, J.T. Novel collagen scaffolds with predefined internal morphology made by solid freeform fabrication. Biomaterials 24, 1487, 2003.

95. Xiao, Y., Qian, H., Young, W.G., and Bartold, P.M. Tissue engineering for bone regeneration using differentiated alveolar bone cells in collagen scaffolds. Tissue Eng 9, 1167, 2003.

96. George, J., Kuboki, Y., and Miyata, T. Differentiation of mesenchymal stem cells into osteoblasts on honeycomb collagen scaffolds. Biotechnol Bioeng 95, 404, 2006. 
97. Schneider, R.K., Puellen, A., Kramann, R., Raupach, K., Bornemann, J., Knuechel, R., Perez-Bouza, A., and Neuss, $\mathrm{S}$. The osteogenic differentiation of adult bone marrow and perinatal umbilical mesenchymal stem cells and matrix remodelling in three-dimensional collagen scaffolds. Biomaterials 31, 467, 2010.

98. Lisignoli, G., Fini, M., Giavaresi, G., Nicoli Aldini, N., Toneguzzi, S., and Facchini, A. Osteogenesis of large segmental radius defects enhanced by basic fibroblast growth factor activated bone marrow stromal cells grown on nonwoven hyaluronic acid-based polymer scaffold. Biomaterials 23, 1043, 2002.

99. Kim, J., Kim, I.S., Cho, T.H., Lee, K.B., Hwang, S.J., Tae, G., Noh, I., Lee, S.H., Park, Y., and Sun, K. Bone regeneration using hyaluronic acid-based hydrogel with bone morphogenic protein- 2 and human mesenchymal stem cells. Biomaterials 28, 1830, 2007.

100. Abbah, S., Lu, W., Chan, D., Cheung, K., Liu, W., Zhao, F., $\mathrm{Li}$, Z., Leong, J., and Luk, K. Osteogenic behavior of alginate encapsulated bone marrow stromal cells: An in vitro study. I Mater Sci Mater Med 19, 2113, 2008.

101. Li, C., Vepari, C., Jin, H.-J., Kim, H.J., and Kaplan, D.L. Electrospun silk-BMP-2 scaffolds for bone tissue engineering. Biomaterials 27, 3115, 2006.

102. Meinel, L., Betz, O., Fajardo, R., Hofmann, S., Nazarian, A., Cory, E., Hilbe, M., McCool, J., Langer, R., VunjakNovakovic, G., Merkle, H.P., Rechenberg, B., Kaplan, D.L., and Kirker-Head, C. Silk based biomaterials to heal critical sized femur defects. Bone 39, 922, 2006.

103. Bakos, D., Soldan, M., and Hernandez-Fuentes, I. Hydroxyapatite-collagen-hyaluronic acid composite. Biomaterials 20, 191, 1999.

104. Solchaga, L.A., Temenoff, J.S., Gao, J.Z., Mikos, A.G., Caplan, A.I., and Goldberg, V.M. Repair of osteochondral defects with hyaluronan- and polyester-based scaffolds. Osteoarthritis Cartilage 13, 297, 2005.

105. Schumann, D., Ekaputra, A.K., Lam, C.X.F., and Hutmacher, D.W. Biomaterials/scaffolds. Design of bioactive, multiphasic PCL/collagen type I and type II-PCL-TCP/collagen composite scaffolds for functional tissue engineering of osteochondral repair tissue by using electrospinning and FDM techniques. Methods Mol Med 140, 101, 2007.

106. Rouget, C. Des substances amylacées dans les tissus des animaux, spécialement des Articulés (chitine). Comp Rend Acad Sci Ser III 48, 792, 1859.

107. Suh, J.K., and Matthew, H.W. Application of chitosanbased polysaccharide biomaterials in cartilage tissue engineering: a review. Biomaterials 21, 2589, 2000.

108. Lahiji, A., Sohrabi, A., Hungerford, D.S., and Frondoza, C.G. Chitosan supports the expression of extracellular matrix proteins in human osteoblasts and chondrocytes. I Biomed Mater Res 51, 586, 2000.

109. Kurita, K. Chemistry and application of chitin and chitosan. Polym Degradation Stability 59, 117, 1997.

110. Shi, C., Zhu, Y., Ran, X., Wang, M., Su, Y., and Cheng, T. Therapeutic potential of chitosan and its derivatives in regenerative medicine. J Surg Res 133, 185, 2006.

111. Muzzarelli, R., Baldassarre, V., Conto, F., Ferrara, P., Biagini, G., Gazzanelli, G., and Vasi, V. Biological activity of chitosan: ultrastructural study. Biomaterials 9, 247, 1988.

112. Denuziere, A., Ferrier, D., Damour, O., and Domard, A. Chitosan-chondroitin sulfate and chitosan-hyaluronate polyelectrolyte complexes: biological properties. Biomaterials 19, 1275, 1998.
113. Di Martino, A., Sittinger, M., and Risbud, M.V. Chitosan: a versatile biopolymer for orthopaedic tissue-engineering. Biomaterials 26, 5983, 2005.

114. Nordtveit, R.J., Vârum, K.M., and Smidsrd, O. Degradation of partially $\mathrm{N}$-acetylated chitosans with hen egg white and human lysozyme. Carbohydr Polym 29, 163, 1996.

115. Varum, K.M., Myhr, M.M., Hjerde, R.J., and Smidsrod, O. In vitro degradation rates of partially $\mathrm{N}$-acetylated chitosans in human serum. Carbohydr Res 299, 99, 1997.

116. Shin, S.Y., Park, H.N., Kim, K.H., Lee, M.H., Choi, Y.S., Park, Y.J., Lee, Y.M., Ku, Y., Rhyu, I.C., Han, S.B., Lee, S.J., and Chung, C.P. Biological evaluation of chitosan nanofiber membrane for guided bone regeneration. J Periodontol 76, 1778, 2005.

117. Muzzarelli, R., Tarsi, R., Filippini, O., Giovanetti, E., Biagini, G., and Varaldo, P.E. Antimicrobial properties of Ncarboxybutyl chitosan. Antimicrob Agents Chemother 34, 2019, 1990

118. Loke, W.K., Lau, S.K., Yong, L.L., Khor, E., and Sum, C.K. Wound dressing with sustained anti-microbial capability. I Biomed Mater Res 53, 8, 2000.

119. No, H.K., Park, N.Y., Lee, S.H., and Meyers, S.P. Antibacterial activity of chitosans and chitosan oligomers with different molecular weights. Int J Food Microbiol 74, 65, 2002.

120. Biagini, G., Bertani, A., Muzzarelli, R., Damadei, A., DiBenedetto, G., Belligolli, A., Riccotti, G., Zucchini, C., and Rizzoli, C. Wound management with N-carboxybutyl chitosan. Biomaterials 12, 281, 1991.

121. Okamoto, Y., Shibazaki, K., Minami, S., Matsuhashi, A., Tanioka, S., and Shigemasa, Y. Evaluation of chitin and chitosan on open would healing in dogs. J Vet Med Sci 57, 851, 1995.

122. Ueno, H., Yamada, H., Tanaka, I., Kaba, N., Matsuura, M., Okumura, M., Kadosawa, T., and Fujinaga, T. Accelerating effects of chitosan for healing at early phase of experimental open wound in dogs. Biomaterials 20, 1407, 1999.

123. Azad, A.K., Sermsintham, N., Chandrkrachang, S., and Stevens, W.F. Chitosan membrane as a wound-healing dressing: characterization and clinical application. $\underline{\text { J Biomed }}$ Mater Res B Appl Biomater 69, 216, 2004.

124. Bertram, U., and Bodmeier, R. In situ gelling, bioadhesive nasal inserts for extended drug delivery: In vitro characterization of a new nasal dosage form. Eur J Pharm Sci 27, 62, 2006.

125. Chatelet, C., Damour, O., and Domard, A. Influence of the degree of acetylation on some biological properties of chitosan films. Biomaterials 22, 261, 2001.

126. Varum, K.M., Anthonsen, M.W., Grasdalen, H., and Smidsrod, O. Determination of the degree of N-acetylation and the distribution of $\mathrm{N}$-acetyl groups in partially $\mathrm{N}$ deacetylated chitins (chitosans) by high-field n.m.r. spectroscopy. Carbohydr Res 211, 17, 1991.

127. Pangburn, S.H., Trescony, P.V., and Heller, J. Lysozyme degradation of partially deacetylated chitin, its films and hydrogels. Biomaterials 3, 105, 1982.

128. Hankiewicz, J., and Swierczek, E. Lysozyme in human body fluids. Clin Chim Acta 57, 205, 1974.

129. Muzzarelli, R.A.A. Biochemical significance of exogenous chitins and chitosans in animals and patients. Carbohydr Polym 20, 7, 1993.

130. Torsteinsdottir, I., Hakansson, L., Hallgren, R., Gudbjornsson, B., Arvidson, N.-G., and Venge, P. Serum lysozyme: a potential marker of monocyte/macrophage activity in rheumatoid arthritis. Rheumatology 38, 1249, 1999. 
131. Teijón, C., Olmo, R., Dolores Blanco, M., Romero, A., and Marİa Teijón, J. Effects of lead administration at low doses by different routes on rat spleens. Study of response of splenic lymphocytes and tissue lysozyme. Toxicology 191, 245, 2003.

132. Rabea, E.I., Badawy, M.E.T., Stevens, C.V., Smagghe, G., and Steurbaut, W. Chitosan as antimicrobial agent: applications and mode of action. Biomacromolecules 4, 1457, 2003.

133. Prudden, J.F., Migel, P., Hanson, P., Friedrich, L., and Balassa, L. The discovery of a potent pure chemical woundhealing accelerator. Am J Surg 119, 560, 1970.

134. Peluso, G., Petillo, O., Ranieri, M., Santin, M., Ambrosio, L., Calabró, D., Avallone, B., and Balsamo, G. Chitosan-mediated stimulation of macrophage function. Biomaterials 15, 1215, 1994.

135. Mori, T. Effects of chitin and its derivatives on the proliferation and cytokine production of fibroblasts in vitro. Biomaterials 18, 947, 1997.

136. Nishimura, K., Nishimura, S., Nishi, N., Saiki, I., Tokura, S., and Azuma, I. Immunological activity of chitin and its derivatives. Vaccine 2, 93, 1984.

137. Jameela, S.R., Misra, A., and Jayakrishnan, A. Cross-linked chitosan microspheres as carriers for prolonged delivery of macromolecular drugs. I Biomater Sci 6, 621, 1994.

138. Maruyama, M., and Ito, M. In vitro properties of a chitosanbonded self-hardening paste with hydroxyapatite granules. J Biomed Mater Res 32, 527, 1996.

139. Muzzarelli, R.A., Biagini, G., Bellardini, M., Simonelli, L., Castaldini, C., and Fratto, G. Osteoconduction exerted by methylpyrrolidinone chitosan used in dental surgery. Biomaterials 14, 39, 1993.

140. Muzzarelli, R.A., Zucchini, C., Ilari, P., Pugnaloni, A., Mattioli Belmonte, M., Biagini, G., and Castaldini, C. Osteoconductive properties of methylpyrrolidinone chitosan in an animal model. Biomaterials 14, 925, 1993.

141. Muzzarelli, R.A. Stimulatory effect on bone formation exerted by a modified chitosan. Biomaterials 15, 1075, 1994.

142. Lee, Y.M., Park, Y.J., Lee, S.J., Ku, Y., Han, S.B., Choi, S.M., Klokkevold, P.R., and Chung, C.P. Tissue engineered bone formation using chitosan/tricalcium phosphate sponges. J Periodontol 71, 410, 2000.

143. Yeo, Y.-J., Jeon, D.-W., Kim, C.-S., Choi, S.-H., Cho, K.-S., Lee, Y.-K., and Kim, C.-K. Effects of chitosan nonwoven membrane on periodontal healing of surgically created one-wall intrabony defects in beagle dogs. $\underline{\text { J Biomed Mater }}$ Res 72B, 86, 2004.

144. Ang, T.H., Sultana, F.S.A., Hutmacher, D.W., Wong, Y.S., Fuh, J.Y.H., Mo, X.M., Loh, H.T., Burdet, E., and Teoh, S.H. Fabrication of 3D chitosan-hydroxyapatite scaffolds using a robotic dispensing system. Mater Sci Eng C 20, 35, 2002.

145. Yin, Y., Ye, F., Cui, J., Zhang, F., Li, X., and Yao, K. Preparation and characterization of macroporous chitosangelatin/beta-tricalcium phosphate composite scaffolds for bone tissue engineering. J Biomed Mater Res A 67, 844, 2003.

146. Burg, K.J.L., Porter, S., and Kellam, J.F. Biomaterial developments for bone tissue engineering. Biomaterials 21, 2347, 2000.

147. Gopferich, A. Mechanisms of polymer degradation and erosion. Biomaterials 17, 103, 1996.

148. Carmeliet, P. Mechanisms of angiogenesis and arteriogenesis. Nat Med 6, 389, 2000

149. Borenstein, J.T., Weinberg, E.J., Orrick, B.K., Sundback, C., Kaazempur-Mofrad, M.R., and Vacanti, J.P. Microfabrica- tion of three-dimensional engineered scaffolds. Tissue Eng 13, 1837, 2007.

150. Mastrogiacomo, M., Scaglione, S., Martinetti, R., Dolcini, L., Beltrame, F., Cancedda, R., and Quarto, R. Role of scaffold internal structure on in vivo bone formation in macroporous calcium phosphate bioceramics. Biomaterials 27, 3230, 2006.

151. Klawitter, J., and Hulbert, S. Application of porous ceramics for the attachment of load bearing internal orthopedic applications. J Biomed Mater Res 5, 161, 1971.

152. Lewandrowski, K.-U., Gresser, J.D., Bondre, S., Silva, A.E., Wise, D.L., and Trantolo, D.J. Developing porosity of poly(propylene glycol-co-fumaric acid) bone graft substitutes and the effect on osteointegration: a preliminary histology study in rats. J Biomater Sci Polym Ed 11, 879, 2000.

153. Gomes, M., Holtorf, H., Reis, R., and Mikos, A.G. Influence of the porosity of starch-based fiber mesh scaffolds on the proliferation and osteogenic differentiation of bone marrow stromal cells cultured in a flow perfusion bioreactor. Tissue Eng 12, 801, 2006.

154. Zhang, Y., and Zhang, M. Three-dimensional macroporous calcium phosphate bioceramics with nested chitosan sponges for load-bearing bone implants. J Biomed Mater Res 61, 1, 2002.

155. Yang, S., Leong, K.-F., Du, Z., and Chua, C.-K. The design of scaffolds for use in tissue engineering. Part I. Traditional factors. Tissue Eng 7, 679, 2004.

156. Boyan, B.D., Hummert, T.W., Dean, D.D., and Schwartz, Z. Role of material surfaces in regulating bone and cartilage cell response. Biomaterials 17, 137, 1996.

157. Leong, K.F., Cheah, C.M., and Chua, C.K. Solid freeform fabrication of three-dimensional scaffolds for engineering replacement tissues and organs. Biomaterials 24, 2363, 2003.

158. Shen, F., Cui, Y.L., Yang, L.F., Yao, K.D., Dong, X.H., Jia, W.Y., and Shi, H.D. A study on the fabrication of porous chitosan/gelatin network scaffold for tissue engineering. Polym Int 49, 1596, 2000.

159. Zhang, Y., and Zhang, M. Cell growth and function on calcium phosphate reinforced chitosan scaffolds. J Mater Sci Mater Med 15, 255, 2004.

160. Li, Z., Ramay, H.R., Hauch, K.D., Xiao, D., and Zhang, M. Chitosan-alginate hybrid scaffolds for bone tissue engineering. Biomaterials 26, 3919, 2005.

161. Amaral, I.F., Sampaio, P., and Barbosa, M.A. Three-dimensional culture of human osteoblastic cells in chitosan sponges: the effect of the degree of acetylation. J Biomed Mater Res A 76, 335, 2006.

162. Kong, L., Gao, Y., Lu, G., Gong, Y., Zhao, N., and Zhang, X. A study on the bioactivity of chitosan/nano-hydroxyapatite composite scaffolds for bone tissue engineering. Eur Polym J 42, 3171, 2006.

163. Manjubala, I., Scheler, S., B̂ssert, J., and Jandt, K.D. Mineralisation of chitosan scaffolds with nano-apatite formation by double diffusion technique. Acta Biomater 2, 75, 2006

164. Gravel, M., Gross, T., Vago, R., and Tabrizian, M. Responses of mesenchymal stem cell to chitosan-coralline composites microstructured using coralline as gas forming agent. Biomaterials 27, 1899, 2006.

165. Sendemir-Urkmez, A., and Jamison, R.D. The addition of biphasic calcium phosphate to porous chitosan scaffolds enhances bone tissue development in vitro. J Biomed Mater $\underline{\text { Res Part A 81A, 624, } 2007 .}$ 
166. Zheng, J.P., Wang, C.Z., Wang, X.X., Wang, H.Y., Zhuang, H., and Yao, K.D. Preparation of biomimetic three-dimensional gelatin/montmorillonite-chitosan scaffold for tissue engineering. Reactive Funct Polym 67, 780, 2007.

167. Arpornmaeklong, P., Pripatnanont, P., and Suwatwirote, $\mathrm{N}$. Properties of chitosan-collagen sponges and osteogenic differentiation of rat-bone-marrow stromal cells. Int J Oral Maxillofac Surg 37, 357, 2008.

168. Kuo, Y.-C., Yeh, C.-F., and Yang, J.-T. Differentiation of bone marrow stromal cells in poly(lactide-co-glycolide)/ chitosan scaffolds. Biomaterials 30, 6604, 2009.

169. Akman, A.C., Tigli, R.S., Gumusderelioglu, M., and Nohutcu, R.M. Bone morphogenetic protein-6-loaded chitosan scaffolds enhance the osteoblastic characteristics of MC3T3E1 cells. Artif Organs 34, 65, 2010.

170. Hsieh, C.-Y., Tsai, S.-P., Ho, M.-H., Wang, D.-M., Liu, C.-E., Hsieh, C.-H., Tseng, H.-C., and Hsieh, H.-J. Analysis of freeze-gelation and cross-linking processes for preparing porous chitosan scaffolds. 67, 9, 2007.

171. Knaul, J.Z., Hudson, S.M., and Creber, K.A.M. Improved mechanical properties of chitosan fibers. I Appl Polym Sci 72, 1721, 1999.

172. Hirano, S. Wet-spinning and applications of functional fibers based on chitin and chitosan. Macromol Symp 168, 21, 2001.

173. Tuzlakoglu, K., and Reis, R. Formation of bone-like apatite layer on chitosan fiber mesh scaffolds by a biomimetic spraying process. J Mater Sci Mater Med 18, 1279, 2007.

174. Duan, B., Dong, C., Yuan, X., and Yao, K. Electrospinning of chitosan solutions in acetic acid with poly(ethylene oxide). J Biomater Sci Polym Ed 15, 797, 2004.

175. Ohkawa, K., Cha, D., Kim, H., Nishida, A., and Yamamoto, H. Electrospinning of chitosan. Macromol Rapid Commun 25, 1600, 2004.

176. De Vrieze, S., Westbroek, P., Van Camp, T., and Van Langenhove, L. Electrospinning of chitosan nanofibrous structures: feasibility study. J Mater Sci 42, 8029, 2007.

177. Park, W.H., Jeong, L., Yoo, D.I., and Hudson, S. Effect of chitosan on morphology and conformation of electrospun silk fibroin nanofibers. Polymer 45, 7151, 2004.

178. Subramanian, A., Lin, H.Y., Vu, D., and Larsen, G. Synthesis and evaluation of scaffolds prepared from chitosan fibers for potential use in cartilage tissue engineering. Biomed Sci Instrum 40, 117, 2004.

179. Bhattarai, N., Edmondson, D., Veiseh, O., Matsen, F.A., and Zhang, M. Electrospun chitosan-based nanofibers and their cellular compatibility. Biomaterials 26, 6176, 2005.

180. Li, L., and Hsieh, Y.-L. Chitosan bicomponent nanofibers and nanoporous fibers. Carbohydr Res 341, 374, 2006.

181. Chen, Z., Mo, X., and Qing, F. Electrospinning of collagenchitosan complex. Mater Lett 61, 3490, 2007.

182. Yang, X., Chen, X., and Wang, H. Acceleration of osteogenic differentiation of preosteoblastic cells by chitosan containing nanofibrous scaffolds. Biomacromolecules 10, 2772, 2009.

183. Jiang, T., Abdel-Fattah, W.I., and Laurencin, C.T. In vitro evaluation of chitosan/poly(lactic acid-glycolic acid) sintered microsphere scaffolds for bone tissue engineering. Biomaterials 27, 4894, 2006.

184. Geng, L., Feng, W., Hutmacher, D., Wong, Y., Loh, H., and Fuh, J. Direct writing of chitosan scaffolds using a robotic system. Rapid Prototyping J 11, 90, 2005.

185. Kon, E., Muraglia, A., Corsi, A., Bianco, P., Marcacci, M., Martin, I., Boyde, A., Ruspantini, I., Chistolini, P., Rocca,
M., Giardino, R., Cancedda, R., and Quarto, R. Autologous bone marrow stromal cells loaded onto porous hydroxyapatite ceramic accelerate bone repair in critical-size defects of sheep long bones. J Biomed Mater Res 49, 328, 2000.

186. Kruyt, M., Dhert, W., Yuan, H., Wilson, C., van Blitterswijk, C., Verbout, A., and de Bruijn, J. Bone tissue engineering in a critical size defect compared to ectopic implantations in the goat. J Orthop Res 22, 544, 2004.

187. Lucarelli, E., Donati, D., Cenacchi, A., and Fornasari, P.M. Bone reconstruction of large defects using bone marrow derived autologous stem cells. Transfus Apher Sci 30, 169, 2004.

188. Willers, C., Chen, J., Wood, D., Xu, J., and Zheng, M.H. Autologous chondrocyte implantation with collagen bioscaffold for the treatment of osteochondral defects in rabbits. Tissue Eng 11, 1065, 2005.

189. Giannoni, P., Mastrogiacomo, M., Alini, M., Pearce, S.G., Corsi, A., Santolini, F., Muraglia, A., Bianco, P., and Cancedda, R. Regeneration of large bone defects in sheep using bone marrow stromal cells. I Tissue Eng Regen Med 2, 253, 2008.

190. Heath, C.A. Cells for tissue engineering. Trends Biotechnol 18, 17, 2000.

191. Evans, M., and Kaufman, M. Establishment in culture of pluripotential cells from mouse embryos. Nature 292, 154, 1981.

192. Huss, R., Lange, C., Weissinger, E., Kolb, H.-J., and Thalmeier, K. Evidence of peripheral blood-derived, plasticadherent CD34-/low Hematopoietic stem cell clones with mesenchymal stem cell characteristics. Stem cells 18, 252, 2000.

193. Gimble, J.M., and Guilak, F. Adipose-derived adult stem cells: isolation, characterization, and differentiation potential. Cytotherapy 5, 362, 2003.

194. Sarugaser, R., Lickorish, D., Baksh, D., Hosseini, M., and Davies, J. Human umbilical cord perivascular (HUCPV) cells: a source of mesenchymal progenitors. Stem cells 23, 220, 2005.

195. De Coppi, P., Bartsch, G., Siddiqui, M., Xu, T., Santos, C., Perin, L., Mostoslavsky, G., Serre, A., Snyder, E., Yoo, J., Furth, M., Soker, S., and Atala, A. Isolation of amniotic stem cell lines with potential for therapy. Nature 25, 100, 2007.

196. Fukuchi, Y., Nakajima, H., Sugiyama, D., Hirose, I., Kitamura, T., and Tsuji, K. Human placenta-derived cells have mesenchymal stem/progenitor cell potential. Stem cells 22, 649, 2004.

197. Pittenger, M., Mackay, A.M., Beck, S., Jaiswal, R., Douglas, R., Mosca, J.D., Moorman, M.A., Simonetti, D.H., Craig, S., and Marshak, D.R. Multilineage potential of adult human mesenchymal stem cells. Science 284, 143, 1999.

198. Jiang, Y., Jahagirdar, B., Reinhardt, R., Schwartz, R., Keene, C., and Ortiz-Gonzalez, X. Pluripotency of mesenchymal stem cells derived from adult marrow. Nature 418, 41, 2002.

199. Jaiswal, N., Haynesworth, S.E., Caplan, A.I., and Bruder, S.P. Osteogenic differentiation of purified, culture-expanded human mesenchymal stem cells in vitro. I Cell Biochem 64, 295, 1997.

200. Takamizawa, S., Maehata, Y., Imai, K., Senoo, H., Sato, S., and Hata, R.-I. Effects of ascorbic acid and ascorbic acid 2phosphate, a long-acting vitamin $\mathrm{C}$ derivative, on the proliferation and differentiation of human osteoblast-like cells. Cell Biol Int 28, 255, 2004. 
201. Bellows, C.G., Heersche, J.N.M., and Aubin, J.E. Inorganic phosphate added exogenously or released from [beta]glycerophosphate initiates mineralization of osteoid nodules in vitro. Bone Miner 17, 15, 1992.

202. Gerstenfeld, L.C., Chipman, S.D., Glowacki, J., and Lian, J.B. Expression of differentiated function by mineralizing cultures of chicken osteoblasts. Dev Biol 122, 49, 1987.

203. Koshihara, Y., Kawamura, M., Oda, H., and Higaki, S. Calcification in human osteoblastic cell line derived from periosteum. Biochem Biophys Res Commun 145, 651, 1987.

204. Subramaniam, M., Colvard, D., Keeting, P.E., Rasmussen, K., Riggs, B.L., and Spelsberg, T.C. Glucocorticoid regulation of alkaline phosphatase, osteocalcin, and proto-oncogenes in normal human osteoblast-like cells. J Cell Biochem 50, 411, 1992.

205. Maniatopoulos, C., Sodek, J., and Melcher, A. Bone formation in vitro by stromal cells obtained from bone marrow of young adult rats. Cell Tissue Res 254, 317, 1988.

206. Canalis, E., and Agnusdei, D. Insulin-like growth factors and their role in osteoporosis. Calcif Tissue Int 58, 133, 1996.

207. Mendes, S.C., Van den Brink, I., De Bruijn, J.D., and Van Blitterswijk, C.A. In vivo bone formation by human bone marrow cells: effect of osteogenic culture supplements and cell densities. J Mater Sci Mater Med 9, 855, 1998.

208. Lee, Y.M., Park, Y.J., Lee, S.J., Ku, Y., Han, S.B., Klokkevold, P.R., and Chung, C.P. The bone regenerative effect of platelet-derived growth factor-BB delivered with a chitosan/tricalcium phosphate sponge carrier. J Periodontol 71, 418, 2000.

209. Boyan, B., Bonewald, L., Paschalis, E., Lohmann, C., Rosser, J., Cochran, D., Dean, D., Schwartz, Z., and Boskey, A.L. Osteoblast-mediated mineral deposition in culture is dependent on surface microtopography. Calcif Tissue Int 71, 519, 2002.

210. Govinden, R., and Bhoola, K.D. Genealogy, expression, and cellular function of transforming growth factor-[beta]. Pharmacol Ther 98, 257, 2003.

211. Dean D. Effect of transforming growth factor 2 on marrowinfused foam poly(propylene fumarate) tissue-engineered constructs for the repair of critical-size cranial defects in rabbits. Tissue Eng 11, 923, 2005.

212. Gomez, G., Korkiakoski, S., Gonzalez, M.-M., Lansman, S., Ella, V., Salo, T., Kellomaki, M., Ashammakhi, N., and Arnaud, E. Effect of FGF and polylactide scaffolds on calvarial bone healing with growth factor on biodegradable polymer scaffolds. J Craniofac Surg 17, 935, 2006.

213. Osathanon, T., Linnes, M.L., Rajachar, R.M., Ratner, B.D., Somerman, M.J., and Giachelli, C.M. Microporous nanofibrous fibrin-based scaffolds for bone tissue engineering. Biomaterials 29, 4091, 2008.

214. Lian, J.B., and Stein, G.S. Concepts of osteoblast growth and differentiation: basis for modulation of bone cell development and tissue formation. Crit Rev Oral Biol Med 3, 269, 1992.

215. Owen, T.A., Aronow, M., Shalhoub, V., Barone, L.M., Wilming, L., Tassinari, M.S., Kennedy, M.B., Pockwinse, S., Lian, J.B., and Stein, G.S. Progressive development of the rat osteoblast phenotype in vitro: reciprocal relationships in expression of genes associated with osteoblast proliferation and differentiation during formation of the bone extracellular matrix. I Cell Physiol 143, 420, 1990.

216. Sabokbar, A., Millett, P., Myer, B., and Rushton, N. A rapid, quantitative assay for measuring alkaline phosphatase activity in osteoblastic cells in vitro. Bone Miner 27, 57, 1994.
217. Toquet, J., Rohanizadeh, R., Guicheux, J., Couillaud, S., Passuti, N., Daculsi, G., and Heymann, D. Osteogenic potential in vitro of human bone marrow cells cultured on macroporous biphasic calcium phosphate ceramic. J Biomed Mater Res 44, 98, 1999.

218. Weiner, S. Biomineralization: a structural perspective. I Struct Biol 163, 229, 2008.

219. Werb, Z. ECM and Cell surface proteolysis: regulating cellular ecology. Cell 91, 439, 1997.

220. Klokkevold, P.R. Osteogenesis enhanced by chitosan (poly$\mathrm{N}$-acetyl glucosaminoglycan) in vitro. J Periodontol 67, 1170, 1996.

221. Cai, K., Yao, K., Cui, Y., Lin, S., Yang, Z., Li, X., Xie, H., Qing, T., and Luo, J. Surface modification of poly (D, Llactic acid) with chitosan and its effects on the culture of osteoblasts in vitro. J Biomed Mater Res 60, 398, 2002.

222. Cai, K., Hu, Y., Jandt, K., and Wang, Y. Surface modification of titanium thin film with chitosan via electrostatic selfassembly technique and its influence on osteoblast growth behavior. J Mater Sci Mater Med 19, 499, 2008.

223. Bumgardner, J.D., Chesnutt, B.M., Yuan, Y., Yang, Y., Appleford, M., Oh, S., McLaughlin, R., Elder, S.H., and Ong, J.L. The integration of chitosan-coated titanium in bone: an in vivo study in rabbits. Implant Dentistry 16, 66, 2007.

224. Coutinho, D., Pashkuleva, I., Alves, C., Marques, A., Neves, N., and Reis, R. The effect of chitosan on the in vitro biological performance of chitosan-poly(butylene succinate) blends. Biomacromolecules 9, 1139, 2008.

225. Mohammadi, Y., Soleimani, M., Fallahi-Sichani, M., Gazme, A., Haddadi-Asl, V., Arefian, E., Kiani, J., Moradi, R., Atashi, A., and Ahmadbeigi, N. Nanofibrous poly(epsilon-caprolactone)/poly(vinyl alcohol)/chitosan hybrid scaffolds for bone tissue engineering using mesenchymal stem cells. Int J Artif Organs 30, 204, 2007.

226. Holtorf, H., Jansen, J., and Mikos, A. Ectopic bone formation in rat marrow stromal cell/titanium fiber mesh scaffold constructs: effect of initial cell phenotype. Biomaterials 26, 6208, 2005.

227. Kasten, P., Vogel, J., Luginbu, R., Niemeyer, P., Tonak, M., Lorenz, H., Helbig, L., Weiss, S., Fellenberg, J., Leo, A., Simank, H.-G., and Richter, W. Ectopic bone formation associated with mesenchymal stem cells in a resorbable calcium deficient hydroxyapatite carrier. Biomaterials 26, 5879, 2005.

228. Trojani, T., Boukhechba, F., Scimeca, J.-C., Vandenbos, F., Michiels, J.-F., Daculsi, G., Boileau, P., Weiss, M., Carle, G., and Rochet, N. Ectopic bone formation using an injectable biphasic calcium phosphate/Si-HPMC hydrogel composite loaded with undifferentiated bone marrow stromal cells. Biomaterials 27, 3256, 2006.

229. Schantz, J.T., Hutmacher, D.W., Chim, H., Ng, K.W., Lim, T.C., and Teoh, S.H. Induction of ectopic bone formation by using human periosteal cells in combination with a novel scaffold technology. Cell Transplant 11, 125, 2002.

230. Cai, X.X., Lin, Y.F., Ou, G.M., Luo, E., Man, Y., Yuan, Q.A., and Gong, P. Ectopic osteogenesis and chondrogenesis of bone marrow stromal stem cells in alginate system. Cell Biol Int 31, 776, 2007.

231. Claase, M.B., de Bruijn, J.D., Grijpma, D.W., and Feijen, J. Ectopic bone formation in cell-seeded poly(ethylene oxide)/poly(butylene terephthalate) copolymer scaffolds of varying porosity. J Mater Sci Mater Med 18, 1299, 2007.

232. Costa-Pinto, A., Correlo, V., Sol, P., Bhattacharya, M., Srouji, S., Livne, E., Reis, R., and Neves, N. Chitosan-poly(butylene 
succinate) scaffolds and human bone marrow stromal cells induce bone repair in a mouse calvaria model. J Tissue Eng Regen Med 2011.[Epub ahead of print]; DOI: 10.1002/term.391

233. Lindsey, R.W., Gugala, Z., Milne, E., Sun, M., Gannon, F.H., and Latta, L.L. The efficacy of cylindrical titanium mesh cage for the reconstruction of a critical-size canine segmental femoral diaphyseal defect. J Orthop Res 24, 1438, 2006.

234. Pearce, A., Richards, R., Milz, S., Schneider, E., and Pearce, S. Animal models for implant biomaterial research in bone: a review. Eur Cell Mater 2, 1, 2007.

235. Fuji, T., Anada, T., Honda, Y., Shiwaku, Y., Koike, H., Kamakura, S., Sasaki, K., and Suzuki, O. Octacalcium phosphate-precipitated alginate scaffold for bone regeneration. Tissue Eng Part A 15, 3525, 2009.

236. Zhang, Z.-Y., Teoh, S.-H., Chong, M.S.K., Lee, E.S.M., Tan, L.-G., Mattar, C.N., Fisk, N.M., Choolani, M., and Chan, J. Neo-vascularization and bone formation mediated by fetal mesenchymal stem cell tissue-engineered bone grafts in critical-size femoral defects. Biomaterials 31, 608, 2010.

237. Fialkov, J.A., Holy, C.E., Shoichet, M.S., and Davies, J.E. In vivo bone engineering in a rabbit femur. J Craniofac Surg 14, 324, 2003.

238. Nasser, N.J., Friedman, A., Friedman, M., Moor, E., and Mosheiff, R. Guided bone regeneration in the treatment of segmental diaphyseal defects: a comparison between resorbable and non-resorbable membranes. Injury 36, 1460, 2005.

239. Mastrogiacomo, M., Corsi, A., Francioso, E., Di Comite, M., Monetti, F., Scaglione, F.A., Crovace, A., Bianco, P., and Cancedda, R. Reconstruction of extensive long bone defects in sheep using resorbable bioceramics based on silicon stabilized tricalcium phosphate. Tissue Eng 12, 1261, 2006.

240. Zhu, L., Liu, W., Cui, L., and Cao, Y.L. Tissue-engineered bone repair of goat femur defects with osteogenically induced bone marrow stromal cells. Tissue Eng 12, 423, 2006.

241. Takahashi, Y., Yamamoto, M., Yamada, K., Kawakami, O., and Tabata, Y. Skull bone regeneration in nonhuman primates by controlled release of bone morphogenetic protein2 from a biodegradable hydrogel. Tissue Eng 13, 293, 2007.

242. Umeda, H., Kanemaru, S., Yamashita, M., Kishimoto, M., Tamura, Y., Nakamura, T., Omori, K., Hirano, S., and Ito, J. Bone regeneration of canine skull using bone marrowderived stromal cells and $\beta$-tricalcium phosphate. Laryngoscope 117, 997, 2007.

243. Yuehuei, H., and Freidman, R. Animal Models in Orthopaedic Research, 1st edition. Boca Raton: CRC press, 1999.

244. Montjovent, M.O., Mathieu, L., Schmoekel, H., Mark, S., Bourban, P.E., Zambelli, P.Y., Laurent-Applegate, L.A., and Pioletti, D.P. Repair of critical size defects in the rat cranium using ceramic-reinforced PLA scaffolds obtained by supercritical gas foaming. J Biomed Mater Res Part A 83A, 41, 2007.

245. Whang, K., Healy, K.E., Elenz, D.R., Nam, E.K., Tsai, D.C., Thomas, C.H., Nuber, G.W., Glorieux, F.H., Travers, R., and Sprague, S.M. Engineering bone regeneration with bioabsorbable scaffolds with novel microarchitecture. Tissue Eng 5, 35, 1999.

246. Stephan, S.J., Tholpady, S.S., Gross, B., Petrie-Aronin, C.E., Botchway, E.A., Nair, L.S., Ogle, R.C., and Park, S.S. Injectable tissue-engineered bone repair of a rat calvarial defect. Laryngoscope 120, 895, 2010.

247. Kim, H.W., Shin, S.Y., Kim, H.E., Lee, Y.M., Chung, C.P., Lee, H.H., and Rhyu, I.C. Bone formation on the apatite- coated zirconia porous scaffolds within a rabbit calvarial defect. J Biomater Appl 22, 485, 2008.

248. Kim, S.J., Lim, J.W., Ryu, J.J., Ahn, J.S., Han, I.H., and Shin, S.W. Effects of four different alloplastic materials on bone regeneration in rabbit calvarial defects. Tissue Eng Regen Med 6, 63, 2009.

249. Yeo, A., Wong, W.J., and Teoh, S.H. Surface modification of PCL-TCP scaffolds in rabbit calvaria defects: evaluation of scaffold degradation profile, biomechanical properties and bone healing patterns. J Biomed Mater Res Part A 93A, $1358,2010$.

250. Holmbom, J., Sodergard, A., Ekholm, E., Martson, M., Kuusilehto, A., Saukko, P., and Penttinen, R. Long-term evaluation of porous poly(epsilon-caprolactone-co-Llactide) as a bone-filling material. J Biomed Mater Res Part A 75A, 308, 2005.

251. Yokoyama, A., Gelinsky, M., Kawasaki, T., Kohgo, T., Konig, U., Pompe, W., and Watari, F. Biomimetic porous scaffolds with high elasticity made from mineralized collagen—an animal study. J Biomed Mater Res Part B 75B, 464, 2005.

252. Chu, T.M.G., Warden, S.J., Turner, C.H., and Stewart, R.L. Segmental bone regeneration using a load-bearing biodegradable carrier of bone morphogenetic protein-2. Biomaterials 28, 459, 2007.

253. van der Donk, S., Buma, P., Aspenberg, P., and Schreurs, B. Similarity of bone ingrowth in rats and goats: a bone chamber study. Comp Med 51, 336, 2001.

254. Lee, J.Y., Nam, S.H., Im, S.Y., Park, Y.J., Lee, Y.M., Seol, Y.J., Chung, C.P., and Lee, S.J. Enhanced bone formation by controlled growth factor delivery from chitosan-based biomaterials. J Control Release 78, 187, 2002.

255. Finkenzeller, G., Arabatzis, M., Geyer, A., Wenger, H., Bannasch, H., and Stark, B. Gene expression profiling reveals PDGF receptor alpha as a target of cell osteoblast co-culture model. Tissue Eng 12, 2889, 2006.

256. Jiang, T., Nukavarapu, S.P., Deng, M., Jabbarzadeh, E., Kofron, M.D., Doty, S.B., Abdel-Fattah, W.I., and Laurencin, C.T. Chitosan-poly(lactide-co-glycolide) microsphere-based scaffolds for bone tissue engineering: In vitro degradation and in vivo bone regeneration studies. Acta Biomater 6, 3457, 2010.

Address correspondence to: Nuno M. Neves, Ph.D.

$3 B^{\prime}$ s Research Group-Biomaterials, Biodegradables and Biomimetics Department of Polymer Engineering University of Minho

Headquarters of the European Institute of Excellence on Tissue Engineering and Regenerative Medicine AvePark, Zona Industrial da Gandra S. Cláudio do Barco 4806-909 Caldas das Taipas Guimarães Portugal

E-mail: nuno@dep.uminho.pt

Received: December 3, 2010 Accepted: June 21, 2011

Online Publication Date: July 28, 2011 
